\title{
Heterosis for Yield Components and Fruit Traits in Tomato under Condition of Fusarium Infection and Biological Control by Antagonistic Bacteria EL- Adl, A. M. M. ${ }^{1}$; K. A. Zaied ${ }^{1}$; A. H. Abd El Hadi' ${ }^{1}$ S. M. Farid ${ }^{2}$; Mervat I. Kamal ${ }^{1}$ and Sally E. A. Ibrahim² \\ ${ }^{1}$ Genetic Department, Faculty of Agriculture, Mansoura University.
}

${ }^{2}$ Hort. Res. Inst., Agric. Res. Center, Giza, Egypt.

\section{ABSTRACT}

This study aimed to induce hybrid genotypes resistant to fusarium wilt disease in tomato, as well as using Bacillus thuringiensis as a biological control agent against Fusarium oxysporum. Four tomato varieties were used in this study to induce $12 \mathrm{~F}_{1}$ hybrids and their reciprocal hybrids via diallel crosses. High significant heterosis relative to the mid-parent was obtained with the largest value by $\mathrm{P}_{1} \times \mathrm{P}_{2}$ for plant height, in addition to significant heterosis was obtained by the reciprocal hybrid for the same trait in fungi and control treatments. The parental variety $\mathrm{P}_{3}$ had the highest mean values of total yield per plant in the four treatments where the bacterial treatment $\mathrm{T}_{4}$ gave the highest mean value of total yield per plant in relation to other treatments. The reciprocal hybrid $\mathrm{P}_{3} \times \mathrm{P}_{1}$ gave the highest mean values in the four treatments for the total weight of fruits per plant which referred to the maternal effect. The hybrid $\mathrm{P}_{2} \times \mathrm{P}_{3}$ gave highly significant values of heterosis in the four treatments for weight of three early collections and total weight of fruits per plant. The results appeared that $B t$ treatments enhanced all traits measured in this study especially chemical parameters. This indicated that $B t$ played a major role in the control of natural infection due to biotic stress. In addition, tomato showed higher heterosis in crosses and reciprocal crosses which depends on the distance between varieties.

Keywords: Heterosis, tomato, Bacillus thuringiensis, Fusarium oxysporum.

\section{INTRODUCTION}

Tomato (Solanum lycopersicum $\mathrm{L}$; $2 \mathrm{n}=24$ ) belongs to Family Solanaceae. Tomato is one of the most important vegetable crops all over the world including Egypt. Tomato is a rich source of vitamin A, C and minerals like $\mathrm{Ca}, \mathrm{P}, \mathrm{K}$ and $\mathrm{Fe}$ (Dhaliwal et al., 2003).

Tomatoes are major contributors of antioxidants such as carotenoids (especially, lycopene and $\beta$-carotene), phenolic, ascorbic acid (vitamin C) and small amounts of vitamin $\mathrm{E}$ in daily diets (Rai et al., 2012). Heterosis is a biological phenomenon manifesting itself in hybrids that are more vital, adaptive and productive than their parents. Heterosis has been explained by over-dominance and by additive effects (Bai and Lindhout, 2007).

Fusarium causes vascular wilt of vegetables, flowers, ornamentals and other important crops. Different host plants are attacked by special forms or races of $F$. oxysporum. The disease caused by this fungus is characterized as a wilted plants, yellowed leaves and minimal/reduced or even total loss/absent crop yield (Pataki et al., 2000). In order to product hybrids that are carriers of resistance gene it is necessary to test reaction of existing material to the pathogen and establish the potential of existing genotypes that can be used in agriculture. Biological control offers an important alternative to synthetic chemicals. The use of bacteria as Bacillus sp., have been investigated because of their properties to produce antifungal metabolites and protect plants from fungal infection (Nourozian et al., 2006).

This study amied to investigate the inheritance of resistance for Fusarium wilt disease in tomato, as well as, using Bacillus thuringiensis as a biological control agent against Fusarium wilt to enhancing the growth and yield traits of tomato.

\section{MATERIALS AND METHODS}

\section{Genetic materials}

Four tomato varieties belong to species Lycopersicon esculentum Mill were used. These parental varieties were Fatma $\left(\mathrm{P}_{1}\right)$, Castel rock $\left(\mathrm{P}_{2}\right)$, Tigerella $\left(\mathrm{P}_{3}\right)$ and Marglop $\left(\mathrm{P}_{4}\right)$. The seeds of these parental varieties were kindly provided from Vegetable Research
Department, Horticulture Research Institute, Agriculture Research Center, Giza, Egypt. Bacterial strain used in this study was Bacillus thuringiensis which kindly provided from Bacillus Genetic Stock Center, Biochemistry Dept., Ohio University, Columbus, USA. This strain was maintained on TGY medium as a complete medium according to Mazza et al., (1992). Fusarium oxypourm ff. used in this study was obtained from Plant Protection Research Institute, Agriculture Research Center, Egypt. PDA medium was used as a complete medium for growing and maintained Fusarium oxyspourm according to Leslie and Summerell (2006).

\section{Experimental design}

The four parental varieties and their $F_{1}, F_{1 r}$ hybrids were arranged in Randomize Complete Blocks Design with three replicates. The seedlings were transplanted to the pots after 45 days from sowing. Soil in pots consists of land soil and sand 1:1 without any source of fertilization. The plants were treated with Fusarium oxyspourm three times weakly after two weeks from transplanting. Plants were three weeks inoculated weakly with bacterial suspension $\left(10^{9}\right.$ cells $\left./ \mathrm{ml}\right)$ at the time of flowering for four times with the rate of $5 \mathrm{ml} /$ plant. Treatments inoculated: control plants without any inoculation by fungi or bacteria $\mathrm{T}_{1}$, plants treated with Fusarium oxyspourm $\mathrm{T}_{2}$, plants treated with $B t+$ Fusarium $\mathrm{T}_{3}$, plants treated with $B t \mathrm{~T}_{4}$. Pots preparation, fertilization and other practices were carried out according to the recommendations of the Egyptian Ministry of Agriculture. Data were recorded from randomly chosen plants of three replications using the following traits; plant height, number of fruits per plant for the first three pickings, weight of fruits per plant of the first three pickings, total number of fruits per plant, total weight of fruits per plant, ascorbic acid content according to Sadasivam and Balasubraminan (1987). The estimation of total phenols was measured according to Bary and Thorpe (1954).

Statistical analysis

Data were collected on $\mathrm{P}_{1}, \mathrm{P}_{2}, \mathrm{~F}_{1}$ and $\mathrm{F}_{1 \mathrm{r}}$ hybrids for yield components and other biochemical traits were subjected to statistical analysis of Randomed Complete Blocks Design as outline by Steel and Torrie (1960). 
Heterosis is the percentage increase of the $F_{1}$ hybrid in relation to the mid - parent according to Singh and Chaudary (1985) as follows;

$$
\begin{aligned}
& H \%=\underline{F}_{1} \frac{-M . P}{M . P} \times 100 \\
& \mathbf{F}_{1}=\sum_{\mathbf{P}(\mathbf{P}-\mathbf{1})} \\
& \text { for all hybrids and } \\
& \text { As } \frac{\sum F_{1} j \text {. }}{P(P-1) / 2} \text { for } F_{1} \text { or } F_{1 r} \text { reciprocals. }
\end{aligned}
$$

\section{RESULTS AND DISCUSSION}

The mean performance of parental varieties and their $F_{1}$ hybrids for plant height, ascorbic acid and phenol compound in the four treatments are presented in Table 1.The results indicated that genotypes showed highly significant differences to all treatments. Plant height showed that the parental genotype Fatma $\left(\mathrm{P}_{1}\right)$ was higher than Castel rock $\left(\mathrm{P}_{2}\right)$ in control $\mathrm{T}_{1}$ and fungi treatment $\mathrm{T}_{2}$. Parent Fatma $\left(\mathrm{P}_{1}\right)$ gave high value in fungi treatment than control which proved the resistance of this variety to Fusarium wilt. The parental variety Fatma $\left(\mathrm{P}_{1}\right)$ had highest mean values in control $T_{1}$ and in fungi and bacterial treatment $\mathrm{T}_{3}$. The parental variety Castel rock $\left(\mathrm{P}_{2}\right)$ had highest mean value in fungi treatment $\mathrm{T}_{2}$ and in bacterial treatment $\mathrm{T}_{4}$ and it had the highest mean value, for ascorbic acid trait. For phenol compound the parental variety Fatma
$\left(\mathrm{P}_{1}\right)$ had the lowest mean values in the four treatments which indicate that, the parental variety Fatma $\left(\mathrm{P}_{1}\right)$ was resistant to Fusarim wilt and bacteria also reduce the infection of disease. The $\mathrm{F}_{1}$ hybrid $\mathrm{P}_{1} \times \mathrm{P}_{2}$ had highest mean value in control $T_{1}$ and in fungi treatment $T_{2}$ and it was higher than $F_{1 r}$ hybrid over the two treatments for plant height. The $\mathrm{F}_{1}$ hybrid $\mathrm{P}_{1} \times \mathrm{P}_{2}$ had highest mean values in the four treatments for ascorbic acid. Phenolic compounds showed that, $F_{1}$ hybrid $P_{1} \times P_{2}$ had a lowest mean value in fungi treatment $T_{2}$ and in fungi and bacterial treatment $T_{3}$, but the $\mathrm{F}_{1 \mathrm{r}}$ reciprocal hybrid $\mathrm{P}_{2} \times \mathrm{P}_{1}$ had lowest mean values in control $T_{1}$ and in bacterial treatment $T_{4}$. The results showed highly significant heterosis relative to the midparent for plant height, with a largest value was $32.8 \%$ for $\mathrm{P}_{1} \times \mathrm{P}_{2}$ in control, while heterosis for the reciprocal hybrid was also significant in control $T_{1}$ and fungi treatment $T_{2}$. The $F_{1}$ hybrid of $\mathrm{P}_{1} \times \mathrm{P}_{2}$ had highly significant values for ascorbic acid in the four treatments. On the other hand, phenol compound was not significant in control $T_{1}$ for $F_{1}$ and their $\mathrm{F}_{1 \mathrm{r}}$, but the $\mathrm{F}_{1}$ hybrid of $\left(\mathrm{P}_{1} \times \mathrm{P}_{2}\right)$ had negative significant values $-30.3 \%$ in fungi treatment $\mathrm{T}_{2}$ and $-54.9 \%$ in fungi and bacteria treatment $\mathrm{T}_{3}$. while, the reciprocal hybrid of $\mathrm{P}_{2} \times \mathrm{P}_{1}$ had highly significant of $-49.6 \%$ in $\mathrm{T}_{4}$ bacterial treatment. The results presented in Table 2 appeared that the parental varitey Fatma $\left(\mathrm{P}_{1}\right)$ was the best

\begin{tabular}{|c|c|c|c|c|c|c|c|c|c|c|c|c|c|}
\hline \multirow{2}{*}{\multicolumn{2}{|c|}{$\begin{array}{l}\text { Traits \& Treat. } \\
\text { Geno \&Hetrosis }\end{array}$}} & \multicolumn{4}{|c|}{ Plant height (cm) } & \multicolumn{4}{|c|}{ Ascorbic acid } & \multicolumn{4}{|c|}{ Phenol compounds } \\
\hline & & $\mathbf{T}_{1}$ & $\mathbf{T}_{2}$ & $\mathbf{T}_{3}$ & $\mathbf{T}_{4}$ & $\mathbf{T}_{1}$ & $\mathbf{T}_{2}$ & T3 & $\mathbf{T}_{4}$ & $T_{1}$ & $T_{2}$ & $\mathbf{T}_{3}$ & $\mathbf{T}_{4}$ \\
\hline$\overline{\mathrm{P}_{1}}$ & & 46.3 & 58 & - & -4 & 17 & 14.6 & 17.3 & 21.3 & 0.226 & 0.613 & 0.203 & 0.346 \\
\hline $\mathrm{P}_{2}$ & & 41 & 43 & - & - & 16.1 & 14.8 & 16.3 & 21.6 & 0.261 & 0.753 & 0.566 & 0.433 \\
\hline M.P & & 43.6 & 50.5 & - & - & 16.5 & 14.7 & 16.8 & 21.3 & 0.243 & 0.683 & 0.384 & 0.389 \\
\hline$F_{1}$ & & 58 & 55.3 & - & - & 18.6 & 16.5 & 19.3 & 26 & 0.341 & 0.476 & 0.173 & 0.226 \\
\hline $\mathrm{F}_{1}$-M.P & & 14.4 & 4.8 & - & - & 2.1 & 1.8 & 2.5 & 4.7 & 0.098 & -0.207 & -0.211 & -0.163 \\
\hline $\mathrm{H}_{1} \%$ & & $32.8^{*}$ & 9.50 & - & - & $12.7^{* *}$ & $12.2^{* *}$ & $15.3^{* *}$ & $21.2^{* \pi}$ & $40.3^{* \pi}$ & $-30.3^{* \pi}$ & $-54.9^{*}$ & $-41.9^{* *}$ \\
\hline & & 53.6 & 56.6 & - & - & 18.1 & 15.4 & 17.8 & 23.6 & 0.293 & 0.791 & 0.336 & 0.196 \\
\hline $\mathrm{F}_{1 \mathrm{r}}$-M.P & & 10 & 6.1 & - & - & 1.6 & 0.7 & 1 & 2.3 & 0.05 & 0.108 & -0.048 & -0.193 \\
\hline $\mathrm{H}_{\mathrm{r}} \%$ & & $22.7^{*}$ & $12.1^{*}$ & - & - & $9.69^{* *}$ & 4.76 & 5.95 & $10.7^{* \pi}$ & $20.5^{*}$ & $15.8^{* *}$ & $12.5^{*}$ & $-49.6^{* *}$ \\
\hline \multirow[b]{2}{*}{ L.S.D } & 0.05 & \multicolumn{4}{|c|}{10.9} & \multirow{2}{*}{\multicolumn{4}{|c|}{$\begin{array}{l}1.16 \\
1.52\end{array}$}} & \multirow{2}{*}{\multicolumn{4}{|c|}{$\begin{array}{l}0.043 \\
0.057\end{array}$}} \\
\hline & 0.01 & \multicolumn{4}{|c|}{14.5} & & & & & & & & \\
\hline$\overline{\mathrm{F}_{1}-\mathrm{F}_{1 \mathrm{r}}}$ & & .4 & -1.3 & - & - & 0.5 & 1.1 & $1.5^{*}$ & $2.4^{*}$ & \multicolumn{4}{|c|}{$\frac{0.057}{-0.315^{* 0}-0.163}$} \\
\hline \multirow{2}{*}{ L.S.D } & 0.05 & \multicolumn{4}{|c|}{12.5} & \multirow{2}{*}{\multicolumn{4}{|c|}{175}} & \multirow{2}{*}{\multicolumn{4}{|c|}{$\begin{array}{l}0.051 \\
0.066\end{array}$}} \\
\hline & 0.01 & \multicolumn{4}{|c|}{16.7} & & & & & & & & \\
\hline
\end{tabular}
parent in control $\mathrm{T}_{1}$ for plant height and ascorbic.

Table 1. Themean performance of parental varieties $P_{1}, P_{2}$ and their hybrids and heterosis for plant height and some of chemical traits under treatments.

$T_{1}$ : Control; $T_{2}$ : Fungi treatment; $T_{3}$ : Fungi and bacteria treatment and $T_{4}:$ Bacterial treatment.

\begin{tabular}{|c|c|c|c|c|c|c|c|c|c|c|c|c|}
\hline \multirow{2}{*}{$\begin{array}{l}\text { Traits \& Treat. } \\
\text { Geno.\& Heterosis }\end{array}$} & \multicolumn{4}{|c|}{ Plant height (cm) } & \multicolumn{4}{|c|}{ Ascorbic acid } & \multicolumn{4}{|c|}{ Phenol compounds } \\
\hline & $\mathbf{T}_{1}$ & $\mathbf{T}_{2}$ & $\mathbf{T}_{3}$ & $\mathbf{T}_{4}$ & $T_{1}$ & $\mathbf{T}_{2}$ & $\mathbf{T}_{3}$ & $\mathbf{T}_{4}$ & $T_{1}$ & $\mathbf{T}_{2}$ & $\mathbf{T}_{3}$ & $\mathbf{T}_{4}$ \\
\hline$\overline{\mathrm{P}_{1}}$ & 46.3 & 58 & - & - & 17 & 14.6 & 17.3 & 21.3 & 0.226 & 0.613 & 0.203 & 0.346 \\
\hline $\mathrm{P}_{3}$ & 40.3 & 60.3 & - & - & 15 & 13.3 & 14.6 & 16.3 & 0.223 & 0.22 & 0.253 & 0.22 \\
\hline M.P & 43.3 & 59.1 & - & - & 16 & 13.9 & 15.9 & 18.8 & 0.224 & 0.416 & 0.228 & 0.283 \\
\hline $\mathrm{F}_{1}$ & 57.3 & 65.3 & - & - & 17.7 & 15.2 & 17.6 & 22.3 & 0.266 & 0.343 & 0.24 & 0.21 \\
\hline $\mathrm{F}_{1}$-M.P & 14 & 6.2 & - & - & 1.7 & 1.25 & 1.7 & 3.5 & 0.042 & -0.073 & 0.012 & -0.073 \\
\hline $\mathrm{H}_{1} \%$ & $32.3^{\circ}$ & 10.3 & - & - & $10.6^{\cdots+x}$ & $8.99^{\circ}$ & $10.6^{n-m}$ & $18.6^{-m}$ & 18.7 & $-17.5^{\ldots \pi}$ & 5.26 & $-25.8^{* n}$ \\
\hline $\mathrm{F}_{1 \mathrm{r}}$ & 47.6 & 40 & - & - & 20.5 & 19.6 & 20 & 22 & 0.27 & 0.196 & 0.12 & 0.183 \\
\hline $\mathrm{F}_{1 \mathrm{r}}$-M.P & 4.3 & 19.1 & - & - & 4.5 & 5.7 & 4.1 & 3.2 & 0.046 & -0.22 & -0.108 & -0.1 \\
\hline $\mathrm{H}_{\mathrm{r}} \%$ & 9.93 & $-32.2^{* \pi}$ & - & - & $28.1^{* \pi}$ & $40.6^{* *}$ & $25.7^{* *}$ & $17^{* \pi}$ & $19.1^{*}$ & $52.8^{* \pi}$ & $-47.3^{* \pi}$ & $-35.3^{* \pi}$ \\
\hline L.S.D & \multicolumn{4}{|c|}{10.9} & \multicolumn{4}{|c|}{1.16} & \multicolumn{4}{|c|}{0.043} \\
\hline 0.01 & \multicolumn{4}{|c|}{14.5} & \multicolumn{4}{|c|}{1.52} & \multicolumn{4}{|c|}{0.057} \\
\hline $\mathrm{F}_{1}-\mathrm{F}_{1 \mathrm{r}}$ & 9.7 & $25.3^{* n}$ & - & - & $-2.8^{* *}$ & $-4.4^{* \cdots}$ & $-2.4^{*}$ & 0.3 & -0.004 & $0.147^{* \pi}$ & $0.12^{* n}$ & 0.027 \\
\hline 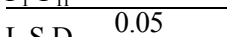 & \multicolumn{4}{|c|}{12.5} & \multicolumn{4}{|c|}{1.33} & \multicolumn{4}{|c|}{0.051} \\
\hline 0.01 & \multicolumn{4}{|c|}{16.7} & \multicolumn{4}{|c|}{1.75} & \multicolumn{4}{|c|}{0.066} \\
\hline
\end{tabular}

$P_{1}$ : Fatma $P_{2}$ : Castel rock $H_{1} \%$ : Heterosis and $H_{r} \%$ : Reciprocal heterosis.

Table 2. The mean performance of parental varieties $P_{1}, P_{3}$ and their hybrids and heterosis for plant height and some of chemical traits under treatments.

$T_{1}$ : Control; $T_{2}$ : Fungi treatment; $T_{3}$ : Fungi and bacteria treatment and $T_{4}$ : Bacteria treatment.

$P_{1}$ : Fatma $P_{3}$ : Tigerella $\mathrm{H}_{1} \%$ : Heterosis and $\mathrm{H}_{2} \%$ : Reciprocal heterosis. 
For phenol compound the parental variety Trigella $\left(\mathrm{P}_{3}\right)$ had the lowest mean values in the four treatments which reverse the resistance of the same parent. The $F_{1}$ hybrid $\mathrm{P}_{1} \times \mathrm{P}_{3}$ was better than its $\mathrm{F}_{1 \mathrm{r}} \mathrm{P}_{3} \times \mathrm{P}_{1}$ in the two treatments for plant height. The reciprocal hybrid $\left(\mathrm{F}_{1 \mathrm{r}}\right)$ $\mathrm{P}_{3} \times \mathrm{P}_{1}$ had the highest mean values in $\mathrm{T}_{1}, \mathrm{~T}_{2}$ and for ascorbic acid. For phenol compound, the lowest mean value showed with $F_{1 r}$ reciprocal hybrid $\mathrm{P}_{3} \times \mathrm{P}_{1}$ in fungi treatment $\mathrm{T}_{2}$. The $\mathrm{F}_{1}$ hybrid between $\mathrm{P}_{1} \times \mathrm{P}_{3}$ showed a low and significant values in control $\mathrm{T}_{1}$ and in fungi treatment $\mathrm{T}_{2}$ for plant height. For ascorbic acid heterosis of the reciprocal hybrid $\mathrm{P}_{3} \times \mathrm{P}_{1}$ showed significant values in control $T_{1}$, fungi treatment $T_{2}$ and fungi and bacterial treatment $\mathrm{T}_{3}$. The hybrid $\mathrm{P}_{1} \times \mathrm{P}_{3}$ showed significant value $(18.6 \%)$ for ascorbic acid in bacterial treatment $\mathrm{T}_{4}$. Phenol compound was not significant in control $\mathrm{T}_{1}$ and fungi and bacterial treatment $T_{3}$ in both of $F_{1} \& F_{1 r}$ hybrids. The reciprocal hybrid $\mathrm{P}_{3} \times \mathrm{P}_{1}$ showed highly significant values of phenolic compounds in fungi treatment $T_{2}$ and in bacterial treatment $\mathrm{T}_{4}$.

The results presented in Table 3 showed that parental variety Fatma $\left(\mathrm{P}_{1}\right)$ recorded the highest mean values of the two treatments for plant height. The parental variety Fatma $\left(\mathrm{P}_{1}\right)$ had the highest mean values in control $T_{1}$, fungi treatment $T_{2}$ and bacterial treatment $T_{4}$ but the parental variety Marlob $\left(\mathrm{P}_{4}\right)$ had highest mean value in fungi and bacterial treatment $\mathrm{T}_{3}$ for ascorbic acid. The parental variety Marglob $\left(\mathrm{P}_{4}\right)$ had the lowest mean values in four treatments for phenolic compounds which reverse to the resistance of Fusarium wilt. The $\mathrm{F}_{1 \mathrm{r}}$ reciprocal hybrid $\mathrm{P}_{4} \times \mathrm{P}_{1}$ had highest mean value in the two treatments for plant height. The results indicated the role of bacteria against fusarium wilt, as well as, phenolic compounds which helping the plants to overcome fungal infection. The results showed the presence of high and positive heterosis for $F_{1}$ reciprocal versus mid-parent under the two treatments for plant height. The $\mathrm{F}_{1 \mathrm{r}}$ reciprocal hybrid $\mathrm{P}_{4} \times \mathrm{P}_{1}$ had significant values in both of fungi and bacterial $\mathrm{T}_{3}$ and bacterial treatment $T_{4}$, while the hybrid $\mathrm{P}_{1} \times \mathrm{P}_{4}$ had highly significant values in control $T_{1}$ and fungi treatment $T_{2}$ for ascorbic acid. Heterosis of phenolic compounds was highly significant in bacterial treatment $\mathrm{T}_{4}$.

Table 3. The mean performance of parental varieties $P_{1}, P_{4}$ and their hybrids and heterosis for plant height and some of chemical traits under treatments.

\begin{tabular}{|c|c|c|c|c|c|c|c|c|c|c|c|c|c|}
\hline \multirow{2}{*}{\multicolumn{2}{|c|}{$\begin{array}{l}\text { Traits\& Treat. } \\
\text { Geno.\& Heterosis }\end{array}$}} & \multicolumn{4}{|c|}{ Plant height (cm) } & \multicolumn{4}{|c|}{ Ascorbic acid } & \multicolumn{4}{|c|}{ Phenol compounds } \\
\hline & & $\mathbf{T}_{1}$ & $\mathbf{T}_{2}$ & $\mathbf{T}_{3}$ & $\mathbf{T}_{4}$ & $\mathbf{T}_{1}$ & $\mathbf{T}_{2}$ & $\mathbf{T}_{3}$ & $\mathbf{T}_{4}$ & $T_{1}$ & $\mathbf{T}_{2}$ & $\mathbf{T}_{3}$ & $\mathbf{T}_{4}$ \\
\hline$\overline{\mathrm{P}_{1}}$ & & 46.3 & 58 & - & - & 17 & 14.6 & 17.3 & 21.3 & 0.226 & 0.613 & 0.203 & 0.346 \\
\hline $\mathrm{P}_{4}$ & & 34 & 27.6 & - & - & 16.1 & 12.6 & 17.5 & 19.8 & 0.176 & 0.161 & 0.113 & 0.156 \\
\hline M.P & & 40.1 & 42.8 & - & - & 16.5 & 13.6 & 17.4 & 20.5 & 0.314 & 0.387 & 0.158 & 0.251 \\
\hline $\mathrm{F}_{1}$ & & 50.8 & 40 & - & - & 18.1 & 15.6 & 17.8 & 21.8 & 0.284 & 0.443 & 0.29 & 0.17 \\
\hline $\mathrm{F}_{1}$-M.P & & 10.7 & -2.8 & - & - & 1.6 & 2 & 0.4 & 1.3 & -0.031 & 0.056 & 0.132 & 0.081 \\
\hline $\mathrm{H}_{1} \%$ & & 26.6 & 6.54 & - & - & $9.69^{* \pi}$ & $14.7^{* *}$ & 2.29 & $6.34^{*}$ & -9.56 & $14.4^{*}$ & $83.5^{* \pi}$ & $-32.3^{* \pi}$ \\
\hline $\mathrm{F}_{1 \mathrm{r}}$ & & 51.6 & 60.3 & - & - & 17.1 & 15.5 & 18 & 22 & 0.283 & 0.72 & 0.613 & 0.213 \\
\hline $\mathrm{F}_{1 \mathrm{r}}$-M.P & & 11.5 & 17.5 & - & - & 0.6 & 1.9 & 0.6 & 1.5 & -0.031 & 0.333 & 0.455 & -0.038 \\
\hline $\mathrm{H}_{\mathrm{r}} \%$ & & $28.5^{*}$ & $40.8^{* \pi}$ & - & - & 3.63 & $13.9^{* *}$ & 3.44 & $7.31^{*}$ & -9.87 & $86^{* \pi}$ & $100^{* *}$ & -15.1 \\
\hline \multirow{2}{*}{ L.S.D } & 0.05 & \multicolumn{4}{|c|}{10.9} & \multicolumn{4}{|c|}{1.16} & \multicolumn{4}{|c|}{0.043} \\
\hline & 0.01 & \multicolumn{4}{|c|}{14.5} & \multicolumn{4}{|c|}{1.52} & \multicolumn{4}{|c|}{0.057} \\
\hline $\mathrm{F}_{1}-\mathrm{F}_{1 \mathrm{r}}$ & & -0.8 & $-20.3^{\prime \prime}$ & - & - & 1 & 0.1 & -0.2 & -0.2 & 0.001 & $-0.277^{\prime \prime}$ & -0.323 & -0.043 \\
\hline \multirow{2}{*}{ L.S.D } & 0.05 & \multicolumn{4}{|c|}{12.5} & \multicolumn{4}{|c|}{1.33} & \multicolumn{4}{|c|}{0.051} \\
\hline & 0.01 & \multicolumn{4}{|c|}{16.7} & \multicolumn{4}{|c|}{1.75} & \multicolumn{4}{|c|}{0.066} \\
\hline
\end{tabular}

$T_{1}$ : Control; $T_{2}$ : Fungi treatment; $T_{3}$ : Fungi and bacteria treatment and $T_{4}$ : Bacterial treatment.

$P_{1}$ : Fatma, $P_{4}$ : Marglob $H_{1} \%$ : Heterosis and $\mathrm{H}_{\mathrm{r}} \%$ : Reciprocal heterosis.

The parental variety Castel rock $\left(\mathrm{P}_{2}\right)$ recorded highest mean value of plant height in control compared with Tigerella $\left(\mathrm{P}_{3}\right)$ in Table 4 . The parental variety Castel rock $\left(\mathrm{P}_{2}\right)$ had highest mean values of ascorbic acid in all treatments which appeared the best value was $21.6 \mathrm{mg}$ in bacterial treatment $\mathrm{T}_{4}$. The parental variety Tigerella $\left(\mathrm{P}_{3}\right)$ was resistant to fusarium wilt disease which do not leading plant genotype to produce highest mean values of phenolic compounds. The $\mathrm{F}_{1 \mathrm{r}}$ hybrid $\mathrm{P}_{3} \times \mathrm{P}_{2}$ recorded the highest mean value of plant height $61.3 \mathrm{~cm}$ in control $\mathrm{T}_{1}$ while, $\mathrm{F}_{1}$ hybrid $\mathrm{P}_{2} \times \mathrm{P}_{3}$ showed highest mean value of $49.6 \mathrm{~cm}$ in fungi treatment $T_{2}$. For ascorbic acid the $F_{1}$ hybrid $P_{2} \times P_{3}$ showed highest mean values in $T_{1}, T_{3}$ and $T_{4}$ but the $F_{1 r}$ reciprocal hybrid $\mathrm{P}_{3} \times \mathrm{P}_{2}$ had highest mean value in fungi treatment $T_{2}$, however, the best value was in bacterial treatment $\mathrm{T}_{4}$. The $\mathrm{F}_{1}$ hybrid $\mathrm{P}_{2} \times \mathrm{P}_{3}$ had lowest mean values of phenolic compounds $(0.22 \mathrm{mg})$ in fungi treatment $\mathrm{T}_{2}$ and in bacterial treatment $\mathrm{T}_{4}$ but the $\mathrm{F}_{1 \mathrm{r}}$ reciprocal hybrid $\mathrm{P}_{3} \times \mathrm{P}_{2}$ had lowest value in control $\mathrm{T}_{1}$ in fungi and bacterial treatment $\mathrm{T}_{3}$. Heterosis for the $\mathrm{F}_{1 \mathrm{r}}$ hybrid $\mathrm{P}_{3} \times \mathrm{P}_{2}$ was significant in control treatment for plant height. The $F_{1}$ hybrid $\mathrm{P}_{2} \times \mathrm{P}_{3}$ showed highly and significant values of ascorbic acid in four treatments and the reciprocal hybrid $\mathrm{P}_{3} \times \mathrm{P}_{2}$ showed highly significant values in four treatments also. The hybrid $\mathrm{P}_{2} \times \mathrm{P}_{3}$ had negative significant heterosis $(-54.7 \%)$ for phenolic compounds in fungi treatment $\mathrm{T}_{2}$ but the $\mathrm{F}_{1 \mathrm{r}}$ reciprocal hybrid $\mathrm{P}_{3} \times \mathrm{P}_{2}$ showed negative and highly significant heterosis $-48.5 \%$ and $-47.9 \%$ in fungi treatment and fungi and bacterial treatment $\mathrm{T}_{3}$, respectively.

The results in Table 5 showed that the parental variety Castel rock $\left(\mathrm{P}_{2}\right)$ showed the best results in the two treatments if compared with the parental variety Marglop $\left(\mathrm{P}_{4}\right)$ for plant hight. The parental variety Castel rock $\left(\mathrm{P}_{2}\right)$ showed the highest mean values in the four treatments versus the parental variety Marglob $\left(\mathrm{P}_{4}\right)$ for ascorbic acid. The parental variety Marglob $\left(\mathrm{P}_{4}\right)$ had highest mean values in the four treatments versus the parental variety Castel rock $\left(\mathrm{P}_{2}\right)$ and the best value was in bacterial treatment $\left(\mathrm{T}_{4}\right)$ for phenolic compounds. The lowest mean value of phenolic compounds was the best which showen in the parental variety $\left(\mathrm{P}_{4}\right)$.

The $\mathrm{F}_{1 \mathrm{r}}$ reciprocal hybrid $\mathrm{P}_{4} \times \mathrm{P}_{2}$ recorded the best mean values for plant height over the two treatments which showed the maternal effect in hybridization. The results 
showed the $\mathrm{F}_{1}$ hybrid $\mathrm{P}_{2} \times \mathrm{P}_{4}$ had high mean values of ascorbic acid in fungi treatment $T_{2}(17.6 \mathrm{mg})$ and in bacterial treatment $\mathrm{T}_{4}(22 \mathrm{mg})$ while, the $\mathrm{F}_{1 \mathrm{r}}$ reciprocal hybrid $\mathrm{P}_{4} \times \mathrm{P}_{2}$ showed the highest mean values in control $\mathrm{T}_{1}$ $(19.3 \mathrm{mg})$ and in fungi and bacterial treatment $(18.6 \mathrm{mg})$ $T_{3}$. The results showed the $F_{1}$ hybrid $P_{2} \times P_{4}$ had the lowest mean value for phenolic compounds. The heterosis of plant height in reciprocal hybrid versus the mid-parent for $\mathrm{P}_{4} \times \mathrm{P}_{2}$ was significant in the two treatments. The $\mathrm{F}_{1 \mathrm{r}}$ reciprocal hybrid $\mathrm{P}_{4} \times \mathrm{P}_{2}$ showed significant content of ascorbic acid in control $T_{1}$ and in fungi and bacterial treatment $T_{3}$, but the hybrid $\mathrm{P}_{2} \times \mathrm{P}_{4}$ showed highly significant value in fungi treatment $T_{2}$ and in bacterial treatment $T_{4}$. Heterosis of phenolic compounds was significant in control $\mathrm{T}_{1}$ among both $\mathrm{F}_{1}$ and their $\mathrm{F}_{1 \mathrm{r}}$. In addition, the hybrid of $\mathrm{P}_{2} \times \mathrm{P}_{4}$ showed significant heterosis percent for phenolic compounds in fungi treatment $T_{2}$, in fungi and bacterial treatment $\mathrm{T}_{3}$ and in bacterial treatment $\mathrm{T}_{4}$.

Table 4. The mean performance of parental varieties $P_{2}, P_{3}$ and their hybrids and heterosis for plant height and some of chemical traits under treatments.

\begin{tabular}{|c|c|c|c|c|c|c|c|c|c|c|c|c|c|}
\hline \multirow{2}{*}{\multicolumn{2}{|c|}{$\begin{array}{l}\text { Traits \& Treat. } \\
\text { Geno.\& Heterosis }\end{array}$}} & \multicolumn{4}{|c|}{ Plant height (cm) } & \multicolumn{4}{|c|}{ Ascorbic acid } & \multicolumn{4}{|c|}{ Phenol compounds } \\
\hline & & $\mathbf{T}_{1}$ & $\mathbf{T}_{2}$ & $\mathbf{T}_{3}$ & $\mathbf{T}_{4}$ & $\mathbf{T}_{1}$ & $\mathbf{T}_{2}$ & $\mathbf{T}_{3}$ & $\mathbf{T}_{4}$ & $\mathbf{T}_{1}$ & $\mathbf{T}_{2}$ & $T_{3}$ & $\mathbf{T}_{4}$ \\
\hline$\overline{\mathrm{P}_{2}}$ & & 41 & 43 & - & - & 16.1 & 14.8 & 16.3 & 21.6 & 0.26 & 0.753 & 0.566 & 0.433 \\
\hline $\mathrm{P}_{3}$ & & 40.3 & 60.3 & - & - & 15 & 13.3 & 14.6 & 16.3 & 0.223 & 0.22 & 0.253 & 0.22 \\
\hline M.P & & 40.6 & 51.6 & - & - & 15.5 & 14.1 & 15.4 & 18.9 & 0.241 & 0.486 & 0.409 & 0.326 \\
\hline $\mathrm{F}_{1}$ & & 55.3 & 49.6 & - & - & 19.3 & 16 & 20.1 & 22.3 & 0.29 & 0.22 & 0.22 & 0.166 \\
\hline $\mathrm{F}_{1}$-M.P & & 14.7 & -2 & - & - & 3.8 & 1.9 & 4.7 & 3.4 & 0.049 & -0.266 & -0.189 & -0.16 \\
\hline $\mathrm{H}_{1} \%$ & & $36.1^{\circ}$ & -3.96 & - & - & $24.5^{-\pi}$ & $13.5^{\infty m}$ & $30.5^{-\infty}$ & $18.6^{\circ \prime}$ & $20.3^{\ldots+}$ & $-54.7^{-\infty}$ & $-46.2^{\cdots \cdots}$ & $-49^{-\infty}$ \\
\hline & & 61.3 & 40 & - & - & 18.6 & 17.7 & 20 & 22 & 0.27 & 0.25 & 0.213 & 0.316 \\
\hline $\mathrm{F}_{1 \mathrm{r}}-\mathrm{M} . \mathrm{P}$ & & 20.7 & -11.6 & - & - & 3.1 & 3.6 & 4.6 & 3.1 & 0.029 & -0.236 & -0.196 & -0.01 \\
\hline $\mathrm{Hr} \%$ & & $50.4^{\cdots \infty}$ & $-22.5^{\circ}$ & - & - & $20^{-\pi}$ & $25.5^{n-m}$ & $29.8^{\ldots+}$ & $17^{*+\infty}$ & 12.5 & $-48.5^{\cdots}$ & $-47.9^{-1}$ & -3.06 \\
\hline \multirow{2}{*}{ L.S.D } & 0.05 & \multicolumn{4}{|c|}{10.9} & \multirow{2}{*}{\multicolumn{4}{|c|}{1.16}} & \multirow{2}{*}{\multicolumn{4}{|c|}{$\begin{array}{l}0.043 \\
0.057\end{array}$}} \\
\hline & 0.01 & \multicolumn{4}{|c|}{14.5} & & & & & & & & \\
\hline$\overline{F_{1}-F_{1 r}}$ & & -6 & 9.6 & - & - & 0.7 & $-1.7^{*}$ & 0.1 & 0.3 & \multicolumn{4}{|c|}{$\begin{array}{r}0 . \\
-0.03\end{array}$} \\
\hline $\mathrm{I} S \mathrm{~S}$ & 0.05 & \multirow{2}{*}{\multicolumn{4}{|c|}{12.5}} & \multirow{2}{*}{\multicolumn{4}{|c|}{1.33}} & \multirow{2}{*}{\multicolumn{4}{|c|}{$\begin{array}{l}0.051 \\
0.066\end{array}$}} \\
\hline & 0.01 & & & & 16.7 & & & & & & & & \\
\hline
\end{tabular}

$T_{1}$ : Control, $T_{2}$ : Fungi treatment, $T_{3}$ : Fungi and bacteria treatment and $T_{4}$ : Bacterial treatment.

$P_{2}$ : Castel rock $P_{3}$ : Tigerella $H_{1} \%$ : Heterosis $H_{r} \%$ : Reciprocal heterosis.

Table 5. The mean performance of parental varieties $P_{2}, P_{4}$ and their hybrids and heterosis for plant height and some of chemical traits under treatments.

\begin{tabular}{|c|c|c|c|c|c|c|c|c|c|c|c|c|c|}
\hline \multirow{2}{*}{\multicolumn{2}{|c|}{$\begin{array}{l}\text { Traits \& Treat. } \\
\text { Geno.\& Heterosis }\end{array}$}} & \multicolumn{4}{|c|}{ plant height (cm) } & \multicolumn{4}{|c|}{ Ascorbic acid } & \multicolumn{4}{|c|}{ Phenol compounds } \\
\hline & & $\mathbf{T}_{1}$ & $\mathbf{T}_{2}$ & $\mathbf{T}_{3}$ & $\mathbf{T}_{4}$ & $\mathbf{T}_{1}$ & $\mathbf{T}_{2}$ & $\mathbf{T}_{3}$ & $\mathbf{T}_{4}$ & $T_{1}$ & $\mathbf{T}_{2}$ & $\mathbf{T}_{3}$ & $\mathbf{T}_{4}$ \\
\hline$\overline{\mathrm{P}_{2}}$ & & 41 & 43 & - & - & 16.1 & 14.8 & 16.3 & 21.6 & 0.26 & 0.753 & 0.566 & 0.433 \\
\hline $\mathrm{P}_{4}$ & & 34 & 27.5 & - & - & 16.1 & 12.6 & 17.5 & 19.8 & 0.176 & 0.161 & 0.113 & 0.156 \\
\hline M.P & & 37.5 & 35.3 & - & - & 16.1 & 13.7 & 16.9 & 20.7 & 0.218 & 0.457 & 0.339 & 0.294 \\
\hline $\mathrm{F}_{1}$ & & 54 & 48 & - & - & 18.8 & 17.6 & 18.1 & 22 & 0.286 & 0.266 & 0.196 & 0.186 \\
\hline F1-M.P & & 16.5 & 12.7 & - & - & 2.7 & 3.9 & 1.2 & 1.3 & 0.068 & -0.191 & -0.143 & -0.108 \\
\hline $\mathrm{H}_{1} \%$ & & $43.7^{*}$ & $35.6^{*}$ & - & - & $16.7^{* \pi}$ & $28.4^{* \pi}$ & $7.10^{*}$ & $6.28^{*}$ & $31.2^{\text {** }}$ & $-41.8^{* *}$ & $-42.2^{\pi *}$ & $-36.7^{* \pi}$ \\
\hline $\mathrm{F}_{1 \mathrm{r}}$ & & 58.6 & 48.6 & - & - & 19.3 & 15.6 & 18.6 & 21.8 & 0.326 & 0.616 & 0.4 & 0.293 \\
\hline F1r-M.P & & 21.1 & 13.3 & - & - & 3.2 & 1.9 & 1.7 & 1.1 & 0.108 & 0.159 & 0.061 & -0.001 \\
\hline $\mathrm{Hr} \%$ & & $56.2^{* *}$ & $37.6^{*}$ & - & - & $19.8^{* *}$ & $13.8^{* *}$ & $10.1^{* *}$ & 5.31 & $49.5^{* *}$ & $34.8^{* \pi}$ & $17.9^{\text {** }}$ & -0.34 \\
\hline & 0.05 & \multicolumn{4}{|c|}{10.9} & \multicolumn{4}{|c|}{1.16} & \multicolumn{4}{|c|}{0.043} \\
\hline D & 0.01 & \multicolumn{4}{|c|}{14.5} & \multicolumn{4}{|c|}{1.52} & \multicolumn{4}{|c|}{0.057} \\
\hline $\mathrm{F}_{1}-\mathrm{F}_{1 \mathrm{r}}$ & & -4.6 & -0.6 & - & - & -0.5 & 2 & -0.5 & 0.2 & -0.04 & -0.35 & $-0.204^{*}$ & $-0.107^{m}$ \\
\hline $\mathrm{I} S \mathrm{~S}$ & 0.05 & \multicolumn{4}{|c|}{12.5} & \multicolumn{4}{|c|}{1.33} & \multicolumn{4}{|c|}{0.051} \\
\hline & 0.01 & \multicolumn{4}{|c|}{16.7} & \multicolumn{4}{|c|}{1.75} & \multicolumn{4}{|c|}{0.066} \\
\hline
\end{tabular}

$T_{1}:$ Control, $T_{2}$ : Fungi treatment, $T_{3}$ : Fungi and bacteria treatment and $T_{4}:$ Bacterial treatment.

$P_{2}$ : Castel rock $P_{4}$ : Marglob $H_{1} \%$ : Heterosis $\mathrm{H}_{r} \%$ : Reciprocal heterosis.

The results summarized in Table 6 showed superiority of the parental variety Tigerella $\left(\mathrm{P}_{3}\right)$ over the parental variety Marglop $\left(\mathrm{P}_{4}\right)$ for plant height under the two treatments. Parental variety Marglob $\left(\mathrm{P}_{4}\right)$ had high mean values of ascorbic acid in control $T_{1}$, in fungi and bacterial treatment $\mathrm{T}_{3}$ and in bacterial treatment $\mathrm{T}_{4}$, but parental variety Tigerella $\left(\mathrm{P}_{3}\right)$ had high mean value in fungi treatment $\mathrm{T}_{2}$. The parental variety Marglob $\left(\mathrm{P}_{4}\right)$ showed the lowest mean values in all the four treatments for phenolic compounds and the lowest value was shown in bacterial treatment $\mathrm{T}_{4}$ which proved the role of bacteria to protect plant from wilt disease. The $\mathrm{F}_{1}$ hybrid $\mathrm{P}_{3} \times \mathrm{P}_{4}$ showed high mean value of plant height in control $\mathrm{T}_{1}$, followed by fungi treatment $T_{2}$. On the other hand, the $\mathrm{F}_{1}$ hybrid $\mathrm{P}_{3} \times \mathrm{P}_{4}$ gave highest mean values of ascorbic acid in the four treatments and the best value was in bacterial treatment $T_{4}$. The $\mathrm{F}_{1}$ hybrid $\mathrm{P}_{3} \times \mathrm{P}_{4}$ showed the lowest mean values of ascorbic acid in fungi treatment $T_{2}$ and in fungi and bacterial treatment $T_{3}$, while the reciprocal hybrid $\mathrm{P}_{4} \times \mathrm{P}_{3}$ showed lowest mean values in control $T_{1}$ and in bacterial treatment $\mathrm{T}_{4}$. Heterosis of plant height versus mid-parent for the hybrid $\mathrm{P}_{3} \times \mathrm{P}_{4}$ was highly significant in control $\mathrm{T}_{1}$, while in $F_{1}$ and $F_{1 r}$ had non significant in fungi treatment $\mathrm{T}_{2}$. The reciprocal hybrid $\mathrm{P}_{4} \times \mathrm{P}_{3}$ showed highly significant values in the four treatments for phenol compounds. On the other hand, the hybrid $\mathrm{P}_{3} \times \mathrm{P}_{4}$ gave highest values in the four treatments for ascorbic acid.

Similar results were obtained by Sunil et al., (2013), Singhi and ASati (2011), Biswas et al., (2012), Manojkumar etal., (2016) and Kansouh and Zakher (2011), they found highly significant differences among tomato genotypes for plant height, ascorbic acid, phenolic compounds and fruit yield per plant. The results obtained in Table 7 showed that the parental variety Castel $\operatorname{rock}\left(\mathrm{P}_{2}\right)$ 
had the best mean values in the four treatments for NF3P and TNF versus parental variety Fatma $\left(\mathrm{P}_{1}\right)$. While, parental variety Fatma $\left(\mathrm{P}_{1}\right)$ had the best mean values in the four treatments for WF3P.

Table 6. The mean performance of parental varieties $P_{3}, P_{4}$ and their hybrids and heterosis for plant height and some of chemical traits under treatments.

\begin{tabular}{|c|c|c|c|c|c|c|c|c|c|c|c|c|c|}
\hline \multirow{2}{*}{\multicolumn{2}{|c|}{$\begin{array}{l}\text { Traits \& Treat. } \\
\text { Geno.\& Heterosis }\end{array}$}} & \multicolumn{4}{|c|}{ Plant height (cm) } & \multicolumn{4}{|c|}{ Ascorbic acid } & \multicolumn{4}{|c|}{ Phenol compounds } \\
\hline & & $\mathbf{T}_{1}$ & $\mathbf{T}_{2}$ & $\mathbf{T}_{3}$ & $\mathbf{T}_{4}$ & $\mathbf{T}_{1}$ & $\mathbf{T}_{2}$ & $\mathbf{T}_{3}$ & $\mathbf{T}_{4}$ & $\mathbf{T}_{1}$ & $\mathbf{T}_{2}$ & $\mathbf{T}_{3}$ & $\mathbf{T}_{4}$ \\
\hline$\overline{\mathrm{P}_{3}}$ & & 40.3 & 60.3 & - & - & 15 & 13.3 & 14.6 & 16.3 & 0.223 & 0.22 & 0.253 & 0.22 \\
\hline $\mathrm{P}_{4}$ & & 34 & 27.6 & - & - & 16.1 & 12.6 & 17.5 & 19.8 & 0.176 & 0.161 & 0.113 & 0.156 \\
\hline M.P & & 37.1 & 43.9 & - & - & 15.5 & 12.9 & 16 & 18.1 & 0.199 & 0.19 & 0.183 & 0.188 \\
\hline $\mathrm{F}_{1}$ & & 53.3 & 45.6 & - & - & 19.5 & 15.2 & 18.5 & 23.3 & 0.5 & 0.343 & 0.213 & 0.206 \\
\hline $\mathrm{F}_{1}$-M.P & & 16.2 & 1.7 & & & 4 & 2.3 & 2.5 & 5.2 & 0.301 & 0.153 & 0.03 & 0.018 \\
\hline $\mathrm{H}_{1} \%$ & & $43.4^{* \pi}$ & $3.87^{*}$ & - & - & $25.8^{* \pi}$ & $17.8^{* *}$ & $15.6^{* *}$ & $29.4^{* \pi}$ & $151^{* *}$ & $80.5^{\text {** }}$ & 16.3 & 9.57 \\
\hline $\mathrm{F}_{1 \mathrm{r}}$ & & 42.6 & 49.3 & - & - & 17.3 & 15 & 17.6 & 23 & 0.293 & 0.45 & 0.24 & 0.133 \\
\hline $\mathrm{F}_{1 \mathrm{r}}$-M.P & & 5.5 & 5.4 & & & 1.8 & 2.1 & 1.6 & 4.9 & 0.094 & 0.26 & 0.057 & -0.055 \\
\hline $\mathrm{Hr} \%$ & & 14.8 & 12.3 & - & - & $11.6^{* \pi}$ & $16.2^{* *}$ & $10^{*}$ & $27.1^{* \pi}$ & $47.2^{\text {** }}$ & $136^{* \pi}$ & $31.1^{\text {T* }}$ & $-29.2^{*}$ \\
\hline \multirow{2}{*}{ L.S.D } & 0.05 & \multicolumn{4}{|c|}{10.9} & \multicolumn{4}{|c|}{1.16} & \multicolumn{4}{|c|}{0.043} \\
\hline & 0.01 & \multicolumn{4}{|c|}{14.5} & \multicolumn{4}{|c|}{1.52} & \multicolumn{4}{|c|}{0.057} \\
\hline \multicolumn{2}{|l|}{$\mathrm{F}_{1}-\mathrm{F}_{1 \mathrm{r}}$} & 10.7 & -3.7 & - & - & 2.2 & 0.2 & 0.9 & 0.3 & $0.207^{\pi}$ & $-0.107^{*}$ & -0.027 & $0.073^{*+1}$ \\
\hline \multirow{2}{*}{ L.S.D } & 0.05 & \multicolumn{4}{|c|}{12.5} & \multicolumn{4}{|c|}{1.33} & \multicolumn{4}{|c|}{0.051} \\
\hline & 0.01 & \multicolumn{4}{|c|}{16.7} & \multicolumn{4}{|c|}{1.75} & \multicolumn{4}{|c|}{0.066} \\
\hline
\end{tabular}

$\mathrm{T}_{1}$ : Control; $\mathrm{T}_{2}$ : Fungi treatment; $\mathrm{T}_{3}$ : Fungi and bacteria treatment and $\mathrm{T}_{4}$ : Bacteria treatment

$P_{3}$ : Tigerella $P_{4}$ : Marglob $H_{1} \%$ : Heterosis and $H_{r} \%$ : Reciprocal heterosis.

The results showed that the bacterial treatment was the best in relation to the other treatments of the $\mathrm{F}_{1 \mathrm{r}}$ reciprocal hybrid $\mathrm{P}_{2} \times \mathrm{P}_{1}$ which had high mean values of yield components in the four treatments and the best value was shown in bacterial treatment $\mathrm{T}_{4}$ for NF3P, while the $\mathrm{F}_{1}$ hybrid $\mathrm{P}_{1} \times \mathrm{P}_{2}$ had the highest mean values in the four treatments for TNF. On the other hand, the $\mathrm{F}_{1 \mathrm{r}}$ reciprocal hybrid $\mathrm{P}_{2} \times \mathrm{P}_{1}$ showed highest mean values of yield in control $\mathrm{T}_{1}$, in fungi and bacterial treatment $\mathrm{T}_{3}$ and bacteria treatment $\mathrm{T}_{4}$. The $\mathrm{F}_{1 \mathrm{r}}$ reciprocal hybrid $\mathrm{P}_{2} \times \mathrm{P}_{1}$ showed the highest mean values in the four treatments for TWF. The $\mathrm{F}_{1 \mathrm{r}}$ reciprocal hybrid $\mathrm{P}_{2} \times \mathrm{P}_{1}$ showed significant heterotic values in the four treatments for NF3P. In addition, TNF had highly and significant in the reciprocal hybrid if compared with the hybrid of $\mathrm{P}_{1} \times \mathrm{P}_{2}$ in the four treatments. High significant heterosis of yield was shown in the four treatments for the reciprocal hybrid $\mathrm{P}_{2} \times \mathrm{P}_{1}$ if compared with hybrid $\mathrm{P}_{1} \times \mathrm{P}_{2}$ for TWF.

Table 7. The mean performance of parental varieties $P_{1}, P_{2}$ and their hybrids and heterosis under the four treatments for yield component traits.

\begin{tabular}{|c|c|c|c|c|c|c|c|c|c|c|c|c|c|c|c|c|c|}
\hline \multirow{2}{*}{\multicolumn{2}{|c|}{$\begin{array}{l}\text { Traits\& Treat } \\
\text { Geno.\& Heterosis }\end{array}$}} & \multicolumn{4}{|c|}{ NF3P } & \multicolumn{4}{|c|}{ WF3P } & \multicolumn{4}{|c|}{ TNF } & \multicolumn{4}{|c|}{ TWF } \\
\hline & & $\overline{T_{1}}$ & $T_{2}$ & $\mathbf{T}_{3}$ & $\mathbf{T}_{4}$ & $\mathbf{T}_{1}$ & $\mathbf{T}_{2}$ & $\mathbf{T}_{3}$ & $T_{4}$ & $\mathbf{T}_{1}$ & $T_{2}$ & $\mathbf{T}_{3}$ & $\mathbf{T}_{4}$ & $T_{1}$ & $\mathbf{T}_{2}$ & $T_{3}$ & $T_{4}$ \\
\hline \multicolumn{2}{|c|}{$\frac{\text { Geno.\& Heterosis }}{\mathrm{P}_{1}}$} & 26.6 & 22 & 30.3 & 34 & 0.323 & 0.255 & 0.355 & 0.426 & 75.6 & 60 & 87.6 & 103 & 1.02 & 0.891 & 1.12 & 1.25 \\
\hline \multicolumn{2}{|l|}{$\mathrm{P}_{2}$} & 37.3 & 30.6 & 42 & 48.6 & 0.312 & 0.245 & 0.34 & 0.353 & 81.3 & 68.6 & 97.6 & 114 & 1.06 & 0.826 & 1.15 & 1.51 \\
\hline \multicolumn{2}{|l|}{ M.P } & 31.9 & 26.3 & 36.1 & 41.3 & 0.317 & 0.235 & 0.347 & 0.389 & 78.4 & 64.3 & 92.6 & 108 & 1.04 & 0.858 & 1.13 & 1.38 \\
\hline \multirow{2}{*}{\multicolumn{2}{|c|}{$\begin{array}{l}F_{1} \\
F_{1}-M . P\end{array}$}} & 37.7 & 30.6 & 45 & 51.6 & 0.507 & 0.465 & 0.529 & 0.601 & 119.3 & 91 & 135 & 165 & 1.68 & 1.53 & 1.76 & 1.92 \\
\hline & & 5.8 & 4.3 & 8.9 & 10.3 & 0.19 & 0.23 & 0.182 & 0.212 & 40.9 & 26.7 & 42.4 & 57 & 0.64 & 0.672 & 0.63 & 0.54 \\
\hline \multicolumn{2}{|l|}{$\mathrm{H}_{1} \%$} & $18.2^{* \pi}$ & $16.3^{* *}$ & $24.6^{* \pi}$ & $24.9^{* *}$ & 59.9 & 86 & 52.4 & 56.8 & $52.2^{* *}$ & $41.5^{* \pi}$ & $45.7^{* *}$ & $52.7^{* *}$ & $61.5^{*}$ & $78.3^{*}$ & $55.7^{*}$ & $39.1^{*}$ \\
\hline & 43 & 33.6 & 45.6 & 55.6 & 0.528 & 0.395 & 0.568 & 0.633 & 109.6 & 83.3 & 121.3 & 158 & 1.80 & 1.62 & 1.90 & 2.10 \\
\hline \multirow{2}{*}{\multicolumn{2}{|c|}{$\begin{array}{l}\mathrm{F}_{1 \mathrm{r}}-\mathrm{M} . \mathrm{P} \\
\mathrm{H}_{\mathrm{r}} \%\end{array}$}} & 11.1 & 7.3 & 9.5 & 14.3 & 0.211 & 0.16 & 0.221 & 0.244 & 31.2 & 19 & 28.7 & 50 & 0.76 & 0.762 & 0.77 & 0.72 \\
\hline & & $34.7^{* \pi}$ & $27.7^{*}$ & $26.3^{* \pi}$ & $34.6^{* *}$ & 66.5 & 43.6 & 63.6 & 62.7 & $39.8^{*}$ & $29.5^{* \pi}$ & $30.9^{* *}$ & $46.2^{*}$ & $73.1^{*}$ & $88.8^{*}$ & $68.1^{*}$ & $52.2^{*}$ \\
\hline \multirow{2}{*}{ L.S.D } & 0.05 & \multirow{2}{*}{\multicolumn{4}{|c|}{$\begin{array}{l}2.12 \\
2.79\end{array}$}} & \multirow{2}{*}{\multicolumn{4}{|c|}{$\begin{array}{l}2.51 \\
3.28\end{array}$}} & \multirow{2}{*}{\multicolumn{4}{|c|}{$\begin{array}{l}4.69 \\
6.16\end{array}$}} & \multicolumn{4}{|c|}{0.098} \\
\hline & 0.01 & & & & & & & & & & & & & & & 28 & \\
\hline \multicolumn{2}{|l|}{$\overline{\mathrm{F}_{1}-\mathrm{F}_{1 \mathrm{r}}}$} & $-5.3^{*}$ & $-3^{*}$ & -0.6 & $-4^{*}$ & -0.021 & 0.07 & -0.039 & -0.032 & 9.7 & 7.7 & $13.7^{*}$ & $7^{*}$ & $-0.12^{*}$ & -0.09 & $-0.14^{*}$ & $-0.18^{* 13}$ \\
\hline \multirow{2}{*}{ L.S.D } & 0.05 & \multirow{2}{*}{\multicolumn{4}{|c|}{$\begin{array}{l}2.45 \\
3.22\end{array}$}} & \multirow{2}{*}{\multicolumn{4}{|c|}{$\begin{array}{l}2.89 \\
3.79\end{array}$}} & \multirow{2}{*}{\multicolumn{4}{|c|}{5.42}} & \multirow{2}{*}{\multicolumn{4}{|c|}{$\begin{array}{l}0.113 \\
0.148\end{array}$}} \\
\hline & 0.01 & & & & & & & & & & & & & & & & \\
\hline
\end{tabular}

$T_{1}$ : Control; $T_{2}$ : Fungi treatment; $T_{3}$ : Fungi and bacteria treatment and $T_{4}$ : Bacterial treatment.

$P_{1}$ : Fatma $P_{2}$ : Castel rock $H_{1} \%$ : Heterosis and $H_{r} \%$ : Reciprocal heterosis.

NF3P: Number for fruits of the first three pickings, WF3P: Weight of fruits for the first three pickings, TNF: Total number of fruits and TWF: Total weight of fruits.

The reciprocal hybrid $\left(\mathrm{P}_{2} \times \mathrm{P}_{1}\right)$ showed highly significant heterotic percent in the four treatments for TWF .The results presented in Table 8 showed that the parental variety Tigerella $\left(\mathrm{P}_{3}\right)$ had the highest mean value in the four treatments for number of fruits to the first three pickings NF3P and total number of fruits. While, the parental variety Fatma $\left(\mathrm{P}_{1}\right)$ had highest mean values in control $\mathrm{T}_{1}(0.322 \mathrm{~kg})$ and in bacterial treatment $\mathrm{T}_{4}(0.411$ $\mathrm{kg}$ ) versus the parental variety Tigerella $\left(\mathrm{P}_{3}\right)$ which had the highest mean values in fungi treatment $\mathrm{T}_{2}(0.287 \mathrm{~kg})$ and in fungi and bacteria treatment $T_{3}(0.360 \mathrm{~kg})$ for weight of fruits in the first three pickings. Furthermore, the parental varitey Tigerella $\left(\mathrm{P}_{3}\right)$ had the highest mean values of yield in the four treatments, where bacterial treatment $\mathrm{T}_{4}$ gave the highest mean value of total yield. The $\mathrm{F}_{1}$ hybrid $\mathrm{P}_{1} \times \mathrm{P}_{3}$ had the highest mean values of yield in control $T_{1}$, fungi treatment $T_{2}$ and fungi and bacterial treatment $T_{3}$. However, the $F_{1 r}$ reciprocal hybrid $P_{3} \times P_{1}$ had the highest mean value of yield in bacterial treatment $T_{4}$ for NF3P. The $\mathrm{F}_{1 \mathrm{r}}$ reciprocal hybrid $\mathrm{P}_{3} \times \mathrm{P}_{1}$ showed the highest value in the four treatments for TNF. On the other hand, the $\mathrm{F}_{1}$ hybrid $\mathrm{P}_{1} \times \mathrm{P}_{3}$ gave the highest mean values for weight of fruits in fungi treatment $T_{2}$ and bacterial treatment $T_{4}$. In addition, the $F_{1 r}$ reciprocal hybrid $\mathrm{P}_{3} \times \mathrm{P}_{1}$ showed the highest mean values of fruits weight in control $\mathrm{T}_{1}$ and fungi and bacterial treatment $\mathrm{T}_{3}$

The $F_{1 r}$ reciprocal hybrid $\mathrm{P}_{3} \times \mathrm{P}_{1}$ gave the highest mean value in all treatments for TWF and the best value was shown in bacterial treatment $\mathrm{T}_{4}$ which revered to bacteria enhancing the growth of plants. The $F_{1}$ hybrid 
$\mathrm{P}_{1} \times \mathrm{P}_{3}$ gave the highest heteroic values for early number of yield in control $\mathrm{T}_{1}(36.4 \%)$, fungi treatment $\mathrm{T}_{2}(27.9 \%)$, in fungi and bacteria treatment $\mathrm{T}_{3}(27.8 \%)$ and bacteria treatment $\mathrm{T}_{4}(39.1 \%)$. But, total number of yield the reciprocal hybrid of $\mathrm{P}_{3} \times \mathrm{P}_{1}$ gave the highest and significant values in the four treatments. The reciprocal hybrid of $\mathrm{P}_{3} \times \mathrm{P}_{1}$ gave highly significant values in all treatments for total weight of yield.

The results presented in Table (9) showed that the parental variety $\left(\mathrm{P}_{1}\right)$ among all treatments showed early and total number of fruits and total weight of fruits of traits where the best value gave by bacterial treatments $T_{4}$. The
$F_{1 r}$ reciprocal hybrid $\mathrm{P}_{4} \times \mathrm{P}_{1}$ had high value for early number of fruits in control $\mathrm{T}_{1}$, fungi and bacterial treatment $\mathrm{T}_{3}$ and in bacterial treatment $\mathrm{T}_{4}$, but the $\mathrm{F}_{1}$ hybrid $\mathrm{P}_{1} \times \mathrm{P}_{4}$ gave highest mean value in fungi treatment $T_{2}$. The results showed that the $\mathrm{F}_{1}$ hybrid $\mathrm{P}_{1} \times \mathrm{P}_{4}$ had the highest mean values in all treatments for early weight of fruits, total number of fruits and total weight of fruits. Highly significant heterosis values were obtained by the reciprocal hybrid $\mathrm{P}_{4} \times \mathrm{P}_{1}$ in treatments for early number of fruits while, the $F_{1}$ hybrid $P_{1} \times P_{4}$ had high significant value in all total number of fruits and total weight of fruits.

Table 8. The mean performance of parental varieties $P_{1}, P_{3}$ and their hybrids and heterosis under the four treatments for yield component traits.

\begin{tabular}{|c|c|c|c|c|c|c|c|c|c|c|c|c|c|c|c|}
\hline \multirow{2}{*}{$\begin{array}{l}\text { Traits\& Treat. } \\
\text { Geno.\& Heterosis }\end{array}$} & \multicolumn{4}{|c|}{ NF3P } & \multicolumn{3}{|c|}{ WF3P } & \multicolumn{4}{|c|}{ TNF } & \multicolumn{4}{|c|}{ TWF } \\
\hline & $T_{1}$ & $\mathbf{T}_{2}$ & $\mathbf{T}_{3}$ & $\mathbf{T}_{4}$ & $\mathbf{T}_{2}$ & $\mathbf{T}_{3}$ & $\mathbf{T}_{4}$ & $T_{1}$ & $\mathbf{T}_{2}$ & $\mathbf{T}_{3}$ & $\mathbf{T}_{4}$ & $T_{1}$ & $\mathbf{T}_{2}$ & $\mathbf{T}_{3}$ & $\mathbf{T}_{4}$ \\
\hline$\overline{\mathrm{P}_{1}}$ & 26.6 & 22 & 30.3 & 34 & 0.3230 .255 & 0.355 & 0.426 & 75.6 & 60 & 87.6 & 103 & 1.02 & 0.891 & 1.12 & 1.25 \\
\hline $\mathrm{P}_{3}$ & 30.6 & 26 & 36 & 41.6 & 0.3220 .287 & 0.360 & 0.411 & 79.3 & 63 & 91.6 & 104 & 1.15 & 1.02 & 1.29 & 1.43 \\
\hline M.P & 28.6 & 24 & 33.1 & 37.5 & 0.3220 .271 & 0.357 & 0.418 & 77.4 & 61.5 & 89.6 & 103.5 & 1.08 & 0.955 & 1.20 & 1.34 \\
\hline $\mathrm{F}_{1}$ & 39 & 30.7 & 42.4 & 52.6 & 0.5120 .440 & 0.543 & 0.633 & 87 & 70 & 100 & 121 & 1.66 & 1.41 & 1.71 & 1.87 \\
\hline $\mathrm{F}_{1}$-M.P & 10.4 & 6.7 & 9.3 & 15.1 & $\begin{array}{lll}0.19 & 0.169\end{array}$ & 0.186 & 0.215 & 9.6 & 8.5 & 10.4 & 17.5 & 0.58 & 0.455 & 0.51 & 0.53 \\
\hline $\mathrm{H}_{1} \%$ & $36.4^{* *}$ & $27.9^{* \pi}$ & $28.1^{* \pi}$ & $39.1^{\pi \pi}$ & $59 \quad 62.4$ & 52.1 & 51.4 & $12.4^{* \pi}$ & $13.8^{* \pi}$ & $11.6^{* \pi}$ & $8.73^{* \pi}$ & $53.7^{\pi *}$ & $47.6^{\pi * \pi}$ & $42.5^{* \pi}$ & $39.5^{* \pi}$ \\
\hline $\mathrm{F}_{1 \mathrm{r}}$ & 37.6 & 30.6 & 42.3 & 53.3 & 0.5170 .429 & 0.57 & 0.611 & 92 & 76 & 112 & 137 & 1.91 & 1.73 & 2.02 & 2.15 \\
\hline $\mathrm{F}_{1 \mathrm{r}}$-M.P & 9 & 6.6 & 9.2 & 15.8 & 0.1950 .729 & 0.213 & 0.193 & 14.6 & 14.5 & 22.4 & 33.5 & 0.83 & 0.775 & 0.82 & 0.81 \\
\hline $\mathrm{H}_{\mathrm{r}} \%$ & $31.5^{* *}$ & $27.5^{* x}$ & $27.8^{* \pi}$ & $41^{* *}$ & $19.5 \quad 58.3$ & 59.6 & 46.1 & $18.9^{* \pi}$ & $23.5^{* \pi}$ & $25^{* *}$ & $33^{* *}$ & $76.8^{\pi *}$ & $81.1^{\pi \pi}$ & $68.3^{\pi *}$ & $60.4^{* \pi}$ \\
\hline 0.05 & \multicolumn{4}{|c|}{2.12} & \multicolumn{3}{|c|}{2.51} & \multicolumn{4}{|c|}{4.69} & \multicolumn{4}{|c|}{0.098} \\
\hline 0.01 & \multicolumn{4}{|c|}{2.79} & \multicolumn{3}{|c|}{3.28} & \multicolumn{4}{|c|}{6.16} & \multicolumn{4}{|c|}{0.128} \\
\hline $\mathrm{F}_{1}-\mathrm{F}_{1 \mathrm{r}}$ & 1.4 & 0.1 & 0.1 & -0.7 & -0.0050 .011 & -0.027 & 0.022 & $\begin{array}{ll}-5 & -6 \\
\end{array}$ & -12 & & 10 & -0.25 & $-0.32^{* *}$ & -0.31 & $-0.28^{* *}$ \\
\hline 0.05 & \multicolumn{4}{|c|}{2.45} & \multicolumn{3}{|c|}{2.89} & \multirow{2}{*}{\multicolumn{4}{|c|}{$\begin{array}{l}5.42 \\
7.11\end{array}$}} & \multicolumn{4}{|c|}{0.113} \\
\hline 0.01 & \multicolumn{4}{|c|}{3.22} & \multicolumn{3}{|c|}{3.79} & & & & & \multicolumn{4}{|c|}{0.148} \\
\hline
\end{tabular}

$T_{1}$ : Control; $T_{2}$ : Fungi treatment; $T_{3}$ : Fungi and bacteria treatment and $T_{4}$ : Bacterial treatment .

$P_{1}$ : Fatma $P_{3}$ : Tigerella $H_{1} \%$ : Heterosis and $H_{r} \%$ : Reciprocal heterosis.

NF3P: Number of fruits for the first three pickings, WF3P: Weight of fruits for the first three pickings, TNF: Total number of fruits and TWF: Total weight of fruits.

Table 9. The mean performance of parental varieties $P_{1}, P_{4}$ and their hybrids and heterosis under the four treatments for yield component traits.

\begin{tabular}{|c|c|c|c|c|c|c|c|c|c|c|c|c|c|c|c|}
\hline \multirow{2}{*}{$\begin{array}{l}\text { Traits\& Treat. } \\
\text { Geno.\& } \\
\text { Heterosis }\end{array}$} & \multicolumn{4}{|c|}{ NF3P } & \multicolumn{4}{|c|}{ WF3P } & \multicolumn{4}{|c|}{ TNF } & \multicolumn{3}{|c|}{ TWF } \\
\hline & $\mathbf{T}_{1}$ & $\mathbf{T}_{2}$ & $\mathbf{T}_{3}$ & $\mathbf{T}_{4}$ & $\mathbf{T}_{1}$ & $\mathbf{T}_{2}$ & $\mathbf{T}_{3}$ & $\mathbf{T}_{4}$ & $\mathbf{T}_{1}$ & $\mathbf{T}_{2}$ & $\mathbf{T}_{\mathbf{3}}$ & $\mathbf{T}_{4}$ & $\mathbf{T}_{1}$ & $\mathbf{T}_{\mathbf{2}}$ & $\mathbf{T}_{\mathbf{3}}$ \\
\hline$\overline{\mathrm{P}_{1}}$ & 26.6 & 22 & 30.3 & 34 & 0.323 & 0.255 & 0.355 & 0.426 & 75.6 & 60 & 87.6 & 103 & 1.02 & 0.891 & 1.121 .25 \\
\hline $\mathrm{P}_{4}$ & 24 & 16.6 & 28 & 32.6 & 0.282 & 0.22 & 0.314 & 0.350 & 70 & 52.6 & 84 & 96 & 0.836 & 0.662 & 0.8950 .998 \\
\hline M.P & 25.3 & 19.3 & 29.2 & 33.3 & 0.302 & 0.237 & 0.334 & 0.388 & 72.8 & 56.3 & 85.8 & 99.5 & 1.34 & 0.776 & 1.0071 .12 \\
\hline $\mathrm{F}_{1}$ & 38 & 30.4 & 42.3 & 51.3 & 0.597 & 0.542 & 0.624 & 0.697 & 102 & 81 & 126 & 151 & 1.72 & 1.56 & 1.861 .98 \\
\hline $\mathrm{F}_{1}$-M.P & 12.7 & 11.1 & 13.1 & 18 & 0.295 & 0.305 & 0.29 & 0.309 & 29.2 & 24.7 & 40.2 & 51.5 & 0.38 & 0.784 & 0.8530 .86 \\
\hline $\mathrm{H}_{1} \%$ & $50.2^{2}$ & $57.5^{* \pi}$ & $45.3^{\cdots}$ & 54 & 97.6 & 128 & 86.8 & 79.6 & $40.1^{m}$ & $43.8^{\pi * \pi}$ & $46.8^{* \pi *}$ & $51.7^{* *}$ & $85.3^{\prime \prime}$ & $101^{*}$ & $88 \quad 76.7$ \\
\hline $\mathrm{F}_{1 \mathrm{r}}$ & 39 & 30.3 & 46.3 & 51.4 & 0.531 & 0.358 & 0.551 & 0.612 & 100 & 78.6 & 122 & 145 & 1.52 & 1.17 & $\begin{array}{ll}1.59 & 1.72\end{array}$ \\
\hline $\mathrm{F}_{1 \mathrm{r}}$-M.P & 13.7 & 11 & 17.1 & 18.1 & 0.229 & 0.121 & 0.217 & 0.224 & 27.2 & 22.3 & 36.2 & 45.5 & 0.18 & 0.394 & 0.5830 .6 \\
\hline $\mathrm{Hr} \%$ & $54.1^{\cdots}$ & $56.9^{\cdots+}$ & $59.1^{\cdots}$ & $54.3^{\cdots}$ & 75.8 & 51.1 & 64.9 & 57.7 & 37.3 & $39.6^{n-n}$ & $42.2^{n-1}$ & $45.7^{\cdots}$ & 63.7 & $50.8^{\cdots}$ & $60.7^{\pi+1} 53.5^{\cdots+}$ \\
\hline S 0.05 & \multirow{2}{*}{\multicolumn{4}{|c|}{$\begin{array}{l}2.12 \\
2.79\end{array}$}} & \multirow{2}{*}{\multicolumn{4}{|c|}{$\begin{array}{l}2.51 \\
3.28\end{array}$}} & \multirow{2}{*}{\multicolumn{4}{|c|}{$\begin{array}{l}4.69 \\
6.16\end{array}$}} & \multirow{2}{*}{\multicolumn{3}{|c|}{$\begin{array}{l}0.098 \\
0.128\end{array}$}} \\
\hline L.S.D 0.01 & & & & & & & & & & & & & & & \\
\hline$\overline{F_{1}-F_{1 r}}$ & -1 & 0.1 & -4 & -0.1 & 0.066 & 0.184 & 0.073 & 0.085 & 2 & 2.4 & 4 & 6 & 0.2 & 0.39 & $0.27^{\prime \prime \prime} 0.26$ \\
\hline $\mathrm{S} \mathrm{SD} 0.05$ & \multirow{2}{*}{\multicolumn{4}{|c|}{$\begin{array}{l}2.45 \\
3.22\end{array}$}} & \multirow{2}{*}{\multicolumn{4}{|c|}{2.89}} & \multirow{2}{*}{\multicolumn{4}{|c|}{5.42}} & \multirow{2}{*}{\multicolumn{3}{|c|}{$\begin{array}{l}0.113 \\
0.148\end{array}$}} \\
\hline 0.01 & & & & & & & & & & & & & & & \\
\hline
\end{tabular}

$T_{1}$ : Control; $T_{2}$ : Fungi treatment; $T_{3}$ : Fungi and bacteria treatment and $T_{4}$ : Bacterial treatment

$P_{1}$ : Fatma $P_{4}$ : Marglob $\mathrm{H}_{1} \%$ : Heterosis and $\mathrm{H}_{\mathrm{r}} \%$ : Reciprocal heterosis.

NF3P: Number of fruits for the first three pickings, WF3P: Weight of fruits for the first three pickings, TNF: Total number of fruits and TWF: Total weight of fruits.

The results presented in Table 10 showed that the parental variety Castel rock $\left(\mathrm{P}_{2}\right)$ had the highest value among all treatments for number of fruits for the first three pickings and total number of fruits. The parental variety Tigerella $\left(\mathrm{P}_{3}\right)$ had the highest mean value in all treatments for early yield and total yield. The $F_{1 r}$ reciprocal hybrid $\mathrm{P}_{3} \times \mathrm{P}_{2}$ gave the highest mean values for number of fruits of the three first pickings in control $\mathrm{T}_{1}$, in fungi and bacterial treatment $T_{3}$ and bacterial treatment, but the $F_{1}$ hybrid $\mathrm{P}_{2} \times \mathrm{P}_{3}$ had the highest mean values of 34 in fungi treatment $T_{2}$. The $F_{1 r}$ reciprocal hybrid $P_{3} \times P_{2}$ showed the highest mean values in all treatments for total number of fruits. On the other hand, the $\mathrm{F}_{1}$ hybrid $\mathrm{P}_{2} \times \mathrm{P}_{3}$ gave the highest mean values in all treatments for early weight of yield and total weight of fruits. It was noticed that the highest mean value was obtained by bacterial treatment $\mathrm{T}_{4}$ which revered the important role of bacteria in increasing the total yield of tomato. The number of fruits of three fruits pickings showed significant heterotic values of the reciprocal hybrid $\mathrm{P}_{3} \times \mathrm{P}_{2}$ in control $\mathrm{T}_{1}(12.1 \%)$, fungi and bacteria $\mathrm{T}_{3}(11.8 \%)$ and bacteria treatment $\mathrm{T}_{4}(11.2 \%)$, except $51.9 \%$ heterosis in fungi treatment $T_{2}$ was found in the $F_{1}$ hybrid $\mathrm{P}_{2} \times \mathrm{P}_{3}$. The reciprocal hybrid $\mathrm{P}_{3} \times \mathrm{P}_{2}$ showed highly significant values in all treatments for total number of fruits. However, heterosis of the hybrid $\mathrm{P}_{2} \times \mathrm{P}_{3}$ was significant in all treatments for total weight of fruits. 
Table 10. The mean performance of parental varieties $P_{2}, P_{3}$ and their hybrids and heterosis under the four treatments for yield component traits.

\begin{tabular}{|c|c|c|c|c|c|c|c|c|c|c|c|c|c|c|c|}
\hline \multirow{2}{*}{\multicolumn{2}{|c|}{$\begin{array}{l}\text { Traits\& Treat. } \\
\text { Geno.\& Heterosis }\end{array}$}} & \multicolumn{4}{|c|}{ NF3P } & \multicolumn{4}{|c|}{ WF3P } & \multicolumn{4}{|c|}{ TNF } & \multicolumn{2}{|c|}{ TWF } \\
\hline & & $T_{1}$ & $T_{2}$ & $T_{3}$ & $T_{4}$ & $T_{1}$ & $\mathbf{T}_{2}$ & $T_{3}$ & $T_{4}$ & $T_{1}$ & $T_{2}$ & $T_{3}$ & $\mathbf{T}_{4}$ & $T_{1}$ & $T_{3}$ \\
\hline$\overline{\mathrm{P}_{2}}$ & & 37.3 & 30.6 & 42 & 48.6 & 0.312 & 0.245 & 0.34 & 0.353 & 81.3 & 68.6 & 97.6 & 114 & 1.050 .826 & $1.15 \quad 1.51$ \\
\hline $\mathrm{P}_{3}$ & & 30.6 & 26 & 36 & 41.6 & 0.322 & .287 & 0.360 & 0.411 & 79.3 & 63 & 91.6 & 104 & 1.151 .02 & $1.29 \quad 1.43$ \\
\hline M.P & & 33.9 & 28.3 & 39 & 45.1 & 0.317 & 0.266 & 0.35 & 0.382 & 80.3 & 65.8 & 94.6 & 109 & 1.10 .923 & $1.22 \quad 1.47$ \\
\hline$F_{1}$ & & 37.6 & 34 & 43 & 50.6 & 0.474 & 0.476 & 0.590 & 0.639 & 90.6 & 70.6 & 112 & 133 & $1.81 \quad 1.62$ & $1.88 \quad 2.06$ \\
\hline $\mathrm{F}_{1}$-M.P & & 3.7 & 5.7 & 4 & 5.5 & 0.157 & 0.21 & 0.24 & 0.257 & 10.3 & 4.8 & 17.4 & 24 & $\begin{array}{lll}0.71 & 0.697\end{array}$ & $0.66 \quad 0.59$ \\
\hline$I_{1} \%$ & & $10.9^{* *}$ & 51.9 & 10.3 & 10.9 & 49.5 & 31.8 & 68.5 & 67.3 & 12.8 & 8.25 & $18.3^{* \pi}$ & 22 & $72.4^{* \pi} 75.5^{* *}$ & $54 \quad 40.1^{* \pi}$ \\
\hline & & 38 & 30.6 & 43.6 & 50.7 & 0.382 & 0.312 & 0.415 & 0.462 & 112 & 90 & 131 & 157 & $1.47 \quad 1.21$ & $1.51 \quad 1.67$ \\
\hline${ }_{11}-$ M.P & & 4.1 & 2. & 4.6 & J. & 0.065 & 0.046 & 0.065 & $0 .($ & 31.7 & 24.2 & 36.4 & 48 & $\begin{array}{lll}0.37 & 0.287\end{array}$ & $0.29 \quad 0.2$ \\
\hline & & $12.1^{* \pi}$ & 8.12 & 11.8 & 11.2 & 20.5 & 17.2 & 18.5 & 20.9 & 39.4 & 36.7 & $38.5^{* \pi}$ & 44 & 40 & $23.7^{* \pi} 13.6^{* \pi}$ \\
\hline & 0. & & & .12 & & & 2.5 & & & & 4.6 & & & 0.0 & 998 \\
\hline L.S.D & 0.0 & & & .79 & & & 3.2 & & & & 6. & & & 0.1 & 128 \\
\hline $\mathrm{F}_{1}-\mathrm{F}_{1 \mathrm{r}}$ & & -0.4 & $3.4^{* * 2}$ & -0.6 & -0.1 & 0.92 & 0.164 & -0.24 & 0.177 & -21.4 & $-19.4^{*}$ & $-19^{* * *}$ & -24 & $0.32^{* * 4} 0.41^{* * 8}$ & $0.37^{\text {*** }} 0.39$ \\
\hline L.S.D & $\begin{array}{l}0.05 \\
0.01\end{array}$ & & & $\begin{array}{l}.45 \\
.22\end{array}$ & & & $\begin{array}{l}2.8 \\
3.7\end{array}$ & & & & $\begin{array}{l}5.5 \\
7 .\end{array}$ & & & $\begin{array}{l}0.1 \\
0.1\end{array}$ & \\
\hline
\end{tabular}

$T_{1}:$ Control, $T_{2}$ : Fungi treatment, $T_{3}:$ Fungi and bacteria treatment and $T_{4}:$ Bacterial treatment

$P_{2}$ : Castel rock $P_{3}$ : Tigerella $H_{1} \%$ : Heterosis and $H_{r} \%$ : Reciprocal heterosis.

NF3P: Number of fruits for the first three pickings, WF3P: Weight of fruits for the first three pickings, TNF: Total number of fruits and TWF: Total weight of fruits.

The results which obtained in Table 11 showed that the parental variety Castel rock $\left(\mathrm{P}_{2}\right)$ had the highest mean value in all treatments for early and total yield components versus the parental variety Marglob $\left(\mathrm{P}_{4}\right)$. The $\mathrm{F}_{1}$ hybrid $\mathrm{P}_{2} \times \mathrm{P}_{4}$ gave the highest mean values in all treatments for early and total yield components.

High significant heterosis were obtained in all treatments for the early yield NF3P, TNF and TWF. The results presented in Table 12 showed that the parental variety Tigerella $\left(\mathrm{P}_{3}\right)$ had the highest and best mean values in all treatments for early yield $\{\mathrm{NF} 3 \mathrm{P}$ and WF3P $\}$ and total yield $\{\mathrm{TNF}$ and $\mathrm{TWF}\}$ versus the parental variety Marglob $\mathrm{P}_{4}$. The best values for yield components was shown in bacterial treatment $\mathrm{T}_{4}$ which refferd to the promoting of plant growth which leading to increasing total yield per plant. The $\mathrm{F}_{1}$ hybrid $\mathrm{P}_{3} \times \mathrm{P}_{4}$ had the highest mean value for number of fruits for the first three pickings among all the treatments.

Also, the $\mathrm{F}_{1}$ hybrid $\mathrm{P}_{3} \times \mathrm{P}_{4}$ gave highest mean values for weight of fruits for the first three pickings in control $\mathrm{T}_{1}$ $(0.457 \mathrm{~kg})$ and in fungi treatment $\mathrm{T}_{2}(0.360 \mathrm{~kg})$. Meanwhile, the $F_{1 r}$ reciprocal hybrid $\mathrm{P}_{4} \times \mathrm{P}_{3}$ had highest mean values for the same trait in fungi and bacteria treatment $\mathrm{T}_{3}(0.506 \mathrm{~kg})$ and in bacteria treatment $\mathrm{T}_{4}(0.58$ $\mathrm{kg}$ ). The $\mathrm{F}_{1 \mathrm{r}}$ reciprocal hybrid $\mathrm{P}_{4} \times \mathrm{P}_{3}$ had highest mean values in all treatments for total number of fruits and total weight of fruits but the highest values was shown in bacterial treatment which reflected the maternal effect on these traits. The $\mathrm{F}_{1}$ hybrid $\mathrm{P}_{3} \times \mathrm{P}_{4}$ showed significant heterosis in all treatments for number of fruits for the first three pickings. Furthermore, the $F_{1 r}$ reciprocal hybrid $\mathrm{P}_{4} \times \mathrm{P}_{3}$ gave high mean values for weight of fruits for the first three pickings in fungi and bacteria $\mathrm{T}_{3}(50.1 \%)$ and in bacteria treatment $\mathrm{T}_{4}(52.6 \%)$. Significant heterosis were showed for total number of fruits and total weight of fruits in the reciprocal hybrid $\mathrm{P}_{4} \times \mathrm{P}_{3}$ among all treatments. The effect of maternal heterosis were clear in this hybrid $\left(\mathrm{P}_{4} \times \mathrm{P}_{3}\right)$ for total number of fruits and total weight of fruits. The results of heterosis for yield components were similar to those obtained by Chinedozi et al., (2014), Hussein and Basheer (2016), Hannan etal., (2007), Elsayed (2017) and Alice et al., (2001), they found that tomato hybrids expressed significantly high percentage of positive heterosis over mid-parent for number of flower per plant, number of fruits per plant and fruit weight per plant. Results also showed a direct inhibition of the pathogenic strains manifested by Bacillus sp.

Table 11. The mean performance of parental varieties $P_{2}, P_{4}$ and their hybrids and heterosis under the four treatments for yield component traits.

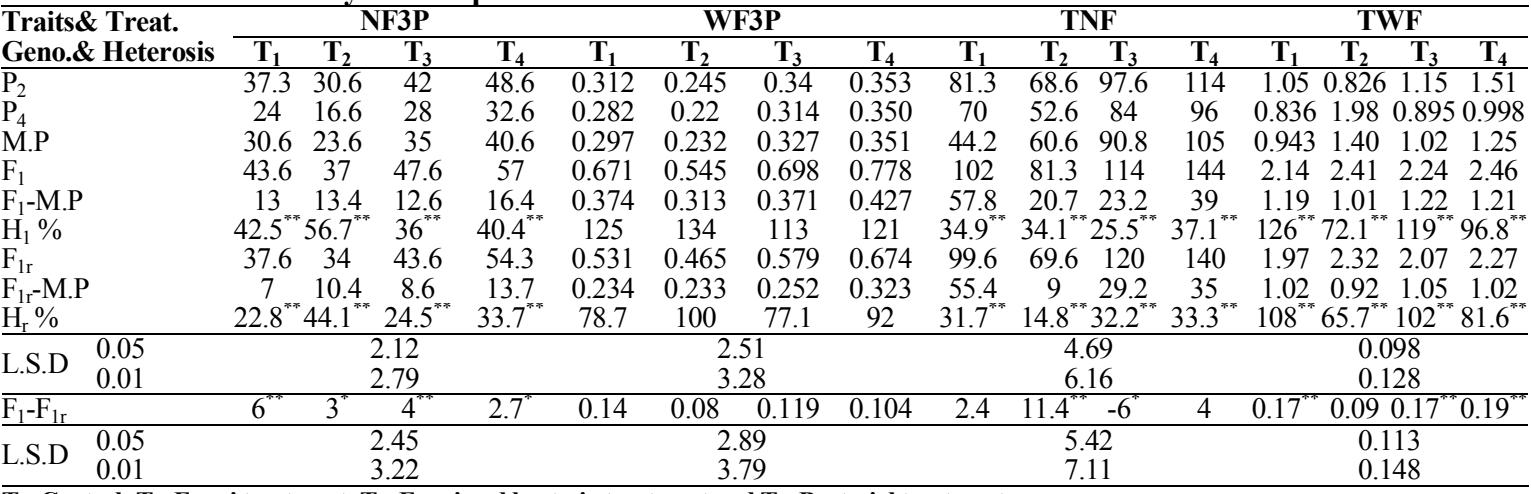

$T_{1}:$ Control; $T_{2}:$ Fungi treatment; $T_{3}:$ Fungi and bacteria treatment and $T_{4}:$ Bacterial treatment.

$\mathrm{P}_{2}$ : Castel rock $\mathrm{P}_{4}$ : Marglob $\mathrm{H}_{1} \%$ : Heterosis and $\mathrm{H}_{\mathrm{r}} \%$ : Reciprocal heterosis.

NF3P: Number of fruits for the first three pickings, WF3P: Weight of fruits for the first three pickings, TNF: Total number of fruits and TWF: Total weight of fruits. 
Table 12. The mean performance of parental varieties $P_{3}, P_{4}$ and their hybrids and heterosis under the four treatments for yield component traits.

\begin{tabular}{|c|c|c|c|c|c|c|c|c|c|c|c|c|c|c|}
\hline \multirow{2}{*}{$\begin{array}{l}\text { Traits\& Treat. } \\
\text { Geno.\& Heterosis }\end{array}$} & \multicolumn{4}{|c|}{ NF3P } & \multicolumn{4}{|c|}{ WF3P } & \multicolumn{3}{|c|}{ TNF } & \multicolumn{3}{|c|}{ TWF } \\
\hline & $\mathbf{T}_{1}$ & $T_{2}$ & $T_{3}$ & $\mathbf{T}_{4}$ & $\mathbf{T}_{1}$ & $T_{2}$ & $\mathbf{T}_{3}$ & $\mathbf{T}_{4}$ & $\mathbf{T}_{2}$ & $\mathbf{T}_{3}$ & $\mathbf{T}_{4}$ & $T_{1}$ & $\mathbf{T}_{2}$ & $\mathbf{T}_{4}$ \\
\hline$\overline{\mathrm{P}_{3}}$ & 30.6 & 26 & 36 & 41.6 & 0.322 & 0.287 & 0.360 & 0.41179 .3 & 63 & 91.6 & 104 & 1.15 & 1.02 & $\begin{array}{ll}1.29 & 1.43\end{array}$ \\
\hline $\mathrm{P}_{4}^{3}$ & 24 & 16.6 & 28 & 32.6 & 0.282 & 0.22 & 0.314 & 0.35070 & 52.6 & 84 & 96 & 0.836 & 0.662 & 0.8950 .998 \\
\hline M.P & 27.3 & 21.3 & 32 & 37.1 & .302 & 0.253 & 0.337 & 0.38174 .6 & 57.8 & 87.8 & 100 & 0.993 & 0.841 & $1.09 \quad 1.21$ \\
\hline $\mathrm{F}_{1}$ & 39.6 & 34.3 & 44 & 52.3 & 0.457 & 0.360 & 0.489 & $0.56 \quad 82$ & 68.3 & 97.3 & 115 & 1.22 & 1.04 & $1.31 \quad 1.61$ \\
\hline $\mathrm{F}_{1}$-M.P & 12.3 & 13 & 12 & 15.2 & 0.155 & 0.107 & 0.152 & $0.179 \quad 7.4$ & 10.5 & 9.5 & 15 & 0.227 & 0.199 & $0.22 \quad 0.4$ \\
\hline $\mathrm{H}_{1} \%$ & $45^{\cdots+}$ & $62.4^{m \ldots}$ & $37.5^{n+}$ & $40.9^{m+n}$ & 51.3 & 42.2 & 45.1 & $47.39 .92^{\cdots \pi}$ & $18.2^{m *}$ & $10.8^{m \infty}$ & $15^{m-n}$ & $22.8^{\cdots *}$ & $23.6^{\pi+\infty}$ & $22.4^{\pi *} 33^{\cdots \pi}$ \\
\hline $\mathrm{F}_{1 \mathrm{r}}$ & 38.3 & 32.6 & 42.6 & 52 & 455 & 0.353 & 0.506 & $0.58 \quad 82$ & 69 & 97.6 & 115 & 1.31 & 1.27 & $1.43 \quad 1.62$ \\
\hline $\mathrm{F}_{1 \mathrm{r}}$-M.P & 11 & 11.3 & 10.6 & 14.9 & 0.153 & 0.1 & 0.169 & $0.199 \quad 7.4$ & 11.2 & 9.8 & 15 & 0.317 & 0.429 & $\begin{array}{lll}0.34 & 0.41\end{array}$ \\
\hline$\underline{\mathrm{H}}_{\mathrm{r}} \%$ & $40.2^{* *}$ & $53^{* *}$ & $33.1^{* \pi}$ & $40.2^{* \pi}$ & 50.6 & 39.5 & 50.1 & $52.69 .92^{* \pi}$ & $19.4^{* \pi}$ & $11.2^{* \pi}$ & $15^{* \pi}$ & $31.9^{* \pi}$ & $51^{* *}$ & $33.6^{* \pi} 33.8^{* \pi}$ \\
\hline 0.05 & \multicolumn{4}{|c|}{2.12} & \multicolumn{4}{|c|}{2.51} & \multicolumn{2}{|c|}{4.69} & \multicolumn{4}{|c|}{0.098} \\
\hline 0.01 & \multicolumn{4}{|c|}{2.79} & \multicolumn{4}{|c|}{3.28} & \multicolumn{2}{|c|}{6.16} & \multicolumn{4}{|c|}{0.128} \\
\hline $\mathrm{F}_{1}-\mathrm{F}_{1 \mathrm{r}}$ & 1.3 & 1.7 & 1.4 & 0.3 & 0.002 & 0.007 & -0.017 & -0.02 & -0.7 & -0.3 & -0.3 & -0.09 & -0.23 & $-0.12-0.01$ \\
\hline 0.05 & \multicolumn{4}{|c|}{2.45} & \multicolumn{4}{|c|}{2.89} & \multicolumn{2}{|c|}{5.42} & \multicolumn{4}{|c|}{0.113} \\
\hline 0.01 & \multicolumn{4}{|c|}{3.22} & \multicolumn{3}{|c|}{3.79} & & \multicolumn{2}{|c|}{7.11} & \multicolumn{4}{|c|}{0.148} \\
\hline
\end{tabular}

$T_{1}$ : Control, $T_{2}$ : Fungi treatment, $T_{3}$ : Fungi and bacteria treatment and $T_{4}$ : Bacterial treatment.

$\mathrm{P}_{3}$ : Tigerella $\mathrm{P}_{4}$ : Marglob $\mathrm{H}_{1} \%$ : Heterosis and $\mathrm{H}_{\mathbf{r}} \%$ : Reciprocal heterosis.

NF3P: Number of fruits for the first three pickings, WF3P: Weight of fruits for the first three pickings, TNF: Total number of fruits and TWF: Total weight of fruits.

In conclusion, most of tomato hybrids induced in this study were resistant to Fusarium wilt disease and the higher values of vegetative and biochemical traits, as well as, yield components traits were obtained under the effect of $B t$ treatment $\mathrm{T}_{4}$. These results indicated that $B t$ played a significant role in the course of controlling natural biotic stress which leading to healthy plants increased yield components as well.

\section{REFERENCES}

Alice, K., K. V. Peter and S. Rajan. 2001. Heterosis for yield components and fruit characters in tomato. Journal of Tropical Agriculture, 39: 5-8.

Bai, Y. and P. Lindhout. 2007. Domestication and breeding of tomatoes: what have we gained and what can we gain in future? Annals of Botany, 100(5):10851094.

Biswas S.K., N. K. Pandey and M. Rajik. 2012. Inductions of defense response in tomato against Fusarium wilt through inorganic chemicals as inducers. J. Plant Pathology \& Microbiology, 3 (4): 1-7.

Bray, H. G. and W.V. Thrope. 1954. Meth. Biochem. Anal. 1: 27-52.

Chinedozi A., C. U. Agbo and G. E. Nwofia. 2014. Hybrid vigor and genetic control of some quantitative traits of tomato (Solanum lycopersicum L.). Journal of Genetics, 4: 30-39.

Dhaliwal, M.S., S. Singh and D.S. Cheema. 2003. Line x tester analysis for yield and processing attributes in tomato. J. Res., 40(1): 49-53.

Elsayed A. Y. A. 2017. Population parameters and pathcoefficient analysis of tomato grown under heat stress. Alexandria Science Exchange Journal, 38 (3): 600- 612.

Hannan M.M, M.B. Ahmed, M.A. Razvy, R. Karim, M. Khatun, A. Haydar, M. Hossain and U.K. Roy. 2007. Heterosis and correlation of yield and yield components in tomato (Lycopersicon esulentum Mill.). American-Eurasian Journal of Scientific Research, 2 (2): 146-150.

Hussein A. S. and N. J. Basheer. 2016. Cost benefit ratio of infected tomato yield by Fusarium wilt disease. Natural and Social Sciences, 4 (4): 103-108.
Kansouh A. M. and A.G. Zakher. 2011. Gene action and combining ability in tomato (Lycopersicon esculentum Mill.) by Line X Tester Analysis. J. Plant Production, Mansoura Univ., 2 (2): 213 227.

Leslie J.F. and B.A. Summerell. 2006.The Fusarium laboratory manual.Blackwell Professional;Ames, IA, USA.

Manojkumar S., H. K. Singh and S. Borthakur. 2016. Evaluation of combining ability for the expression of traits of tomato (Lycopersicon esculentum Mill.) through the Line X Tester analysis. Journal of Agri. Search, 3(2): 127-129.

Mazza P., F. Zani and P. Martelli . 1992. Studies on the antibiotic resistance of Bacillus subtilis strains used in oral bacterio therapy. Boll Chim Farm. 1992, 131(11):401-408.

Nourozian J., H. R. Etebarian and G. Khodakaramian. 2006. Biological control of Fusarium graminearum on wheat by antagonistic bacteria, Nutraceutical and Functional Food, 28- 29.

Pataki J.K., P.M. Michener, N.D. Freeman, R.A. Weinzierl and R. H. Teyker. 2000. Control of Stewart's wilt in sweet corn with seed treatment insecticides. Plant Diseases, 84: 1104-1108.

Rai G.K., R. Kumar, A.K. Singh, P.K. Rai, M. Rai, A.K. Chaturvedi and A.B. Rai. 2012. Changes in antioxidant and phytochemical properties of tomato (Lycopersicon esculentum Mill.) under ambient condition. Pak. J. Bot., 44(2): 667-670.

Sadasivam, S. and T. Balasubraminan. 1987. Practical manual in biochemistry. Tamil Nadu Agricultural University, Coimbatore, P. 14-16.

Singh A. K. and B. S. Asati. 2011. Combining ability and heterosis studies in tomato under bacterial wilt condition. Bangladesh J. Agril. Res.,36(2):313-318.

Singh, R. K. and B.D. Chaudhary. 1985. Biometrical method in quantative genetic analysis. Third edition katyani Publisher, New Dehli, India, 110-112.

Steel, R. G. and J.H. Torri. 1960. Principles and procedure of statistics Mc. Graw Hill book Company. INC, New York.

Sunil K. Y., B. K. Singh, D. K. Baranwa and S. S. Solankey. 2013. Genetic study of heterosis for yield and quality components in tomato (Solanum lycopersicum Mill). Afr. J. Agric. Res., 8(44): 5585-5591. 
قوة الهجين لصفات الثمار ومكونات المحصول في الطماطم تحت ظروف العدوى بالفيوزاريم والمقاومة الحيوية بإستخدام التضاد البكتيري

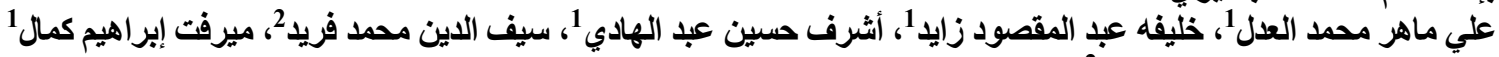

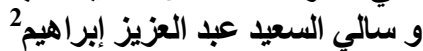

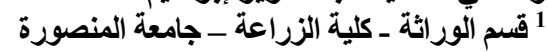

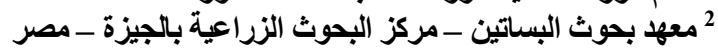

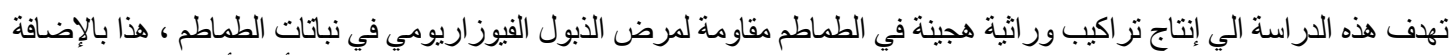

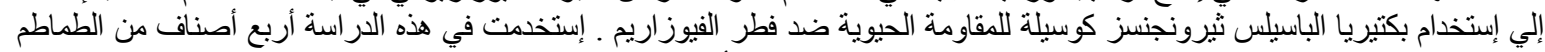

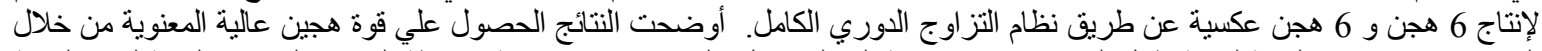

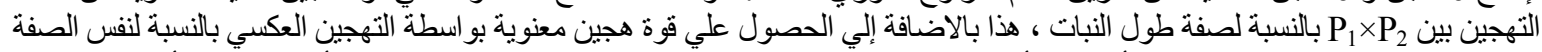

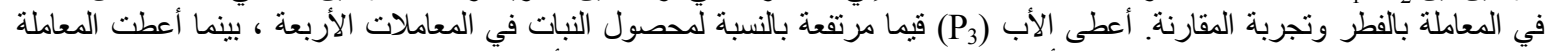

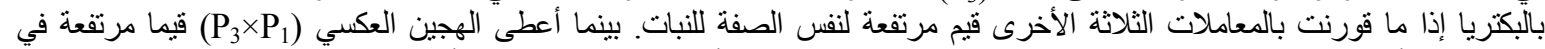

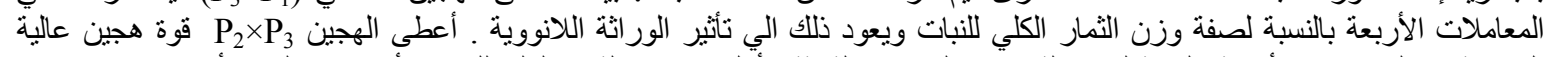

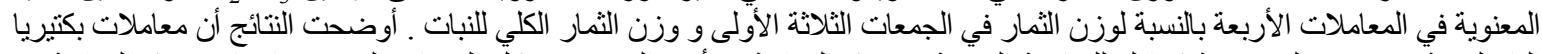

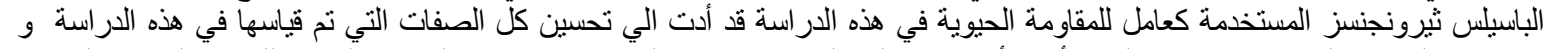

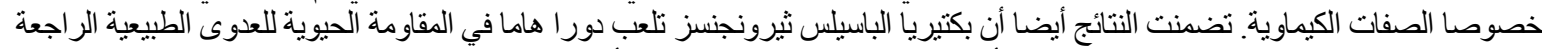

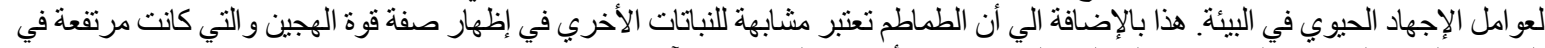
الهجن و الهجن العكسية والتي تعتد علي البعد الوراثي بين الأصناف المستخدمة كآباء. 